\title{
Pengaruh Penggunaan Facebook Terhadap Perilaku Komunikasi Siswa
}

\author{
Arifana*) \\ IAIN Padangsidimpuan, Indonesia \\ koresponden: arifana31@gmail.com
}

\begin{abstract}
Abstrak
Kajian dalam penelitian ini fokus pada media sosial Facebook karena platform tersebut sangat intens dan masif digunakan semua kalangan anak-anak sampai dewasa. Penelitian ini bertujuan untuk melihat pengaruh antara penggunaan Facebook terhadap perilaku komunikasi siswa dengan menggunakan metode pendekatan kuantitatif. Populasi dalam penelitian ini sebanyak 155 orang yang aktif menggunakan Facebook, sedangkan sampel 61 siswa Madrasah Tsanawiyah Aisyiyah yang duduk di kelas VII, VIII dan IX dengan menggunakan teknik Sampling Purposive. Teknik pengumpulan data ialah berupa angket, sedangkan teknik analisis data yang digunakan ialah analisis korelasi berganda. Hasil penelitian menunjukkan bahwa terdapat pengaruh yang signifikan antara penggunaan Facebook terhadap perilaku komunikasi siswa Madrasah Tsanawiyah Aisyiyah Wilayah Sumatera Utara baik secara keseluruhan (simultan) maupun secara individu (parsial).
\end{abstract}

Kata Kunci: Facebook, Perilaku Komunikasi, Aktif

\begin{abstract}
The study in this research focus of Facebook on social media because a platform is very intense and massive to be used by all children and adults. This study aims to look at the influence between the use of social media Facebook on students' communication behavior using quantitative approaches. The population in this study were 155 people who actively used Facebook, while a sample of 61 Madrasah Tsanawiyah Aisyiyah students who sat in class VII, VIII and IX by using Purposive Sampling technique. The data collection technique is in the form of a questionnaire, while the data analysis technique used is multiple correlation analysis. The results showed that there was a significant influence between the use of Facebook on the communication behavior of Madrasah Tsanawiyah Aisyiyah students in the North Sumatra Region both overall (simultaneous) and individually (partial).
\end{abstract}

Keywords: Facebook, Communication Behavior, Active

\section{Pendahuluan}

Pertumbuhan pengguna Facebook di Indonesia didorong oleh program pengenalan internet kepada usia remaja. Banyak remaja yang menggunakan media Facebook sebagai sarana interaktif dalam mendapatkan teman. Adanya Facebook membuat setiap orang seolah-olah memiliki dunia baru, sehingga setiap orang merasa sibuk dengan dunianya sendiri.

Penggunaan media sosial seperti Facebook pada saat sekarang ini sudah sangat masif dan intens. Sepertinya kedua hal itu sudah mejadi bagian dari hidup manusia pada masa kini, terutama kaum remaja. Di kalangan remaja, Facebook adalah suatu hal yang menjadi wadah bagi mereka untuk mendapatkan informasi, berinteraksi, berkomunikasi dengan kawan-kawan yang mereka kenal maupun dari dunia luar yang sama sekali belum mereka kenal. 
Berdasarkan hasil survei yang dilakukan oleh APJII yang diterbitkan pada bulan November 2016, pengguna internet di Indonesia mencapai 132,7 juta pengguna dari total populasi penduduk Indonesia yaitu 256,2 juta orang. Pada tahun 2011 dari tahun 2010. Internet juga telah digunakan oleh berbagai lapisan masyarakat dan kelompok umur, termasuk anak-anak usia 5-17 tahun. Dari 132,7 pengguna internet tersebut, diketahui bahwa pengguna dari kalangan pelajar menempati posisi dua terbesar.

Survei tersebut juga menjelaskan bahwa dari 132,7 juta pengguna internet, paling banyak adalah pengguna Facebook yaitu sebanyak 71,6 juta atau 54\%, diposisi kedua adalah pengguna instagram dengan 19,9 juta atau $15 \%$ pengguna, sedangkan youtube berada diposisi ketiga dengan pengguna sebanyak 14,5 juta atau sebanyak $11 \%$, diikuti oleh pengguna google, twitter dan lain-lain.

Sesuai survei pengguna media sosial yang paling banyak dari kalangan mahasiswa dan siswa. Facebook sudah merupakan bagian dari aktifitas salah satunya adalah kaum pelajar atau siswa sehari-harinya. Dengan penggunaan media sosial yang demikian intens dan dengan durasi yang lama. Sedikit banyaknya akan berpengaruh pada perilaku dan sikap mereka dalam pergaulan sehari-hari.

Antusias mereka terhadap penggunaan internet tentunya membawa hal positif dan negatif terhadap tumbuh kembang anak tersebut. Hal positif yang dapat kita ambil ialah ia dapat mempelajari hal baru atau menambah pengetahuannya terhadap suatu hal seperti belajar mengenal huruf sebagai media penghibur tetapi juga memiliki dampak yang negatif juga.

Masa remaja adalah masa yang mana manusia mulai mengembangkan potensi ataupun kemampuan dalam dirinya. Pada masa tersebut manusia lebih banyak meniru dan mempraktekkan apa yang mereka lihat dan pelajari, karena usia remaja tersebut menurut Peaget (Hurlock, 2004:206) bahwa mereka berada pada masa adolescence. Awal masa remaja bermula dari usia 13 tahun sampai 16 atau 17 tahun, dan akhir masa remaja bermula dari usia 16 atau 17 tahun sampai 18 tahun. Dalam usia ini terjadi proses kematangan mental, emosional, sosial dan fisik. Masa remaja dalam sekolah dimulai sejak akhir Sekolah Dasar hingga saat masuk perguruan tinggi.

Dalam beberapa penelitian yang berkaitan dengan penggunaan media sosial terutama Facebook sering didapatkan hasil bahwa media sosial tersebut memiliki pengaruh terhadap perilaku sehari-hari para penggunanya terutama remaja. Pada masa remaja otak bekerja lebih banyak, dan keingintahuan mereka terhadap sesuatu sangat besar sehingga mereka akan melakukan ataupun mencoba sesuatu yang tidak mereka sadari akan pengaruhnya.

Peneliti memilih siswa Madrasah Tsanawiyah Aisyiyah karena beberapa hal, yang pertama adalah diarenakan lokasi sekolah tersebut yang sangat mudah dijangkau dari tempat peneliti tinggal, sehingga sering beberapa kali peneliti melewati tempat itu dan mengamati bagaimana suasana yang ada dilokasi sekolah tersebut, mulai dari bagaimana para guru memperlakuan muridnya, bagaimana anak-anak belajar dan bermain, hingga bagaimana metode-metode yang para guru pakai dalam melaksanakan kegiatan belajar mengajar.

Alasan yang kedua mengapa peneliti memilih lokasi penelitian di Madrasah Tsanawiyah Aisyiyah karena ada beberapa siswa dari sekolah tersebut yang sudah peneliti amati sangat intens menggunakan Facebook. Salah satu yang peneliti amati memiliki hubungan saudara dengan peneliti, sehingga peneliti tahu sedikit perubahan yang ada pada diri siswa tersebut. 


\section{Komunikasi}

Komunikasi adalah proses sosial dimana individu-individu menggunakan simbolsimbol untuk menciptakan dan menginterpretasikan makna dalam lingkungan mereka. Setiap orang yang hidup dalam masyarakat, sejak bangun tidur sampai tidur kembali, secara kodrati senantiasa terlibat dalam komunikasi. Terjadinya komunikasi adalah sebagai konsekuensi hubungan sosial (social relations).

Kegiatan dalam berkomunikasi merupakan efektifitas dasar manusia. Dengan berkomunikasi, manusia dapat saling berhubungan satu sama lainnya, baik dalam kehidupan di rumah tangga, masyarakat, tempat pekerjaan, atau dimana saja manusia itu berada. Tidak ada manusia yang tidak akan terlibat dalam komunikasi. Secara sederhana Istilah komunikasi atau dalam bahasa inggris yaitu communication, yang merupakan adopsi dari bahasa latin communicatio, dan bersumber dari kata communis yang berarti sama. Sama di sini maksudnya adalah sama makna (Effendy, 2005:9). Dengan demikian ketika kita melakukan percakapan dengan orang lain, maka komunikasi akan terjadi atau berlangsung selama ada kesamaan makna mengenai apa yang dipercakapkan.

Menurut Carl I. Hovland (dalam Effendy, 2005:10) ilmu komunikasi adalah upaya yang sistematis untuk merumuskan secara tegas asas-asas penyampaian informasi serta pembentukan pendapat dan sikap, sedangkan menurut Harold Lasswell dalam karyanya, The Structure and Function of Communication in society. Lasswell menagatakan bahwa cara yang baik untuk menjelaskan komunikasi ialah menjawab pertanyaan sebagai berikut: "Who Says What In Which Channel To Whom With What Effect?"

a. Who (siapa) : Komunikator, orang yang menyampaikan pesan-pesan dalam proses komunikasi massa, bisa per orangan atau mewakili suatu lembaga, organisasi maupun instantsi .

b. Says what (apa yang dikatakan) : pernyataan umum, dapat berupa suatu ide, informasi, opini, pesan dan sikap, yang sangat erat kaitannya dengan masalah analisis pesan.

c. In Which Channel (melalui saluran apa) : media komunikasi atau saluran yang digunakan untuk melaksanakan kegiatan komunikasi.

d. To Whom (kepada siapa) : komunikan atau audiens yang menjadi sasaran komunikasi. Kepada siapa pernyataan tersebut ditunjukkan, berkaitan dengan masalah penerima pesan.

e. With What Effect ( dengan efek apa) : hasil yang dicapai dari usaha penyampain pernyataan umum itu pada sasaran yang dituju.

Paradigma Lasswell menunjukkan bahwa komunikasi meliputi lima unsur sebagai jawaban dari pertanyaan yang diajukan (Effendy, 2005:10), yakni:

a. Komunikator (communicator, source, sender)

Komunikator adalah seseorang atau sekelompok orang yang memberikan informasi kepada lawan bicaranya.

b. Pesan (message)

Pesan merupakan seperangkat lambang yang bermakna yang disampaikan oleh komunikator.

c. Media (channel, media)

Media adalah saluran komunikasi tempat berlalunya pesan dari komunikator kepada komunikan.

d. Komunikan (communicant, receiver, recipient)

Komunikan adalah seseorang atau sekelompok orang yang menerima pesan atau informasi dari komunikator. 


\section{e. Efek (effect, impact, influence)}

Efek adalah tanggapan atau seperangkat reaksi pada komunikan setelah diterpa pesan. Berdasarkan paradigma Lasswell tersebut komunikasi adalah proses penyampaian pesan oleh komunikator kepada komunikan melalui media yang menimbulkan efek tertentu.

Berdasarkan definisi di atas dapat diketahui bahwa komunikasi merupakan proses penyampaian pesan melalui penggunaan simbol/lambang yang dapat menimbulkan efek berupa perubahan tingkah laku yang bisa dilakukan dengan menggunakan media tertentu. Komunikasi memang menyentuh semua aspek kehidupan bermasyarakat, atau sebaliknya semua aspek kehidupan masyarakat menyentuh komunikasi. Justru itu orang melukiskan komunikasi sebagai ubiquitous atau serbahadir (Arifin, 2006:20)

Terdapat tiga unsur penting yang selalu hadir dalam setiap komunikasi, yaitu sumber informasi (receiver), saluran (media), dan penerima informasi (audience). Sumber informasi adalah seseorang atau institusi yang memiliki bahaninformasi (pemberitaan) untuk disebarkan kepada masyarakat luas. Saluran adalah media yang digunakan untuk kegiatan pemberitaan oleh sumber berita, berupa media interpersonal yang digunakan secara tatap muka maupun media massa yang digunakan khalayak umum. Sedangkan audience adalah per orang atau kelompok dan masyarakat yang menjadi sasaran informasi atau yang menerima informasi (Bungin, 2008:57-58).

\section{Komunikasi Antar Pribadi}

Komunikasi antarpribadi adalah interaksi tatap muka antar dua atau beberapa orang, dimana pengirim dapat menyampaikan pesan secara langsung dan penerima pesan dapat menerima dan dapat menanggapai secara langsung. Komunikasi antarpribadi adalah proses pertukaran informasi diantara seseorang dengan orang lain yang dapat langsung diketahui balikannya. Deddy Mulyana mengungkapkan bahwa komunikasi antarpribadi adalah komunikasi antar orang-orang secara tatap muka, yang memungkinkan setiap pesertanya menangkap reaksi orang lain secara langsung, baik secara verbal maupun nonverbal (Suranto, 2011: 3).

\section{Fungsi Komunikasi Antarpribadi}

Fungsi komunikasi antarpribadi ialah berusaha meningkatkan hubungan insan (human relations), menghindari dan mengatasi konflik-konflik pribadi, mengurangi ketidakpastian sesuatu, serta berbagi pengetahuan dan pengalaman dengan orang lain. Melalui komunikasi antarpribadi, individu dapat berusaha membina hubungan yang baik dengan individu lainnya, sehingga menghindari dan mengatasi terjadinya konflik-konflik di antara individu-individu tersebut (Cangara, 2005:56).

Komunikasi antarpribadi sangat potensial untuk menjalankan fungsi instrumental sebagai alat untuk mempengaruhi atau membujuk orang lain, karena manusiadapat menggunakan kelima alat inderanya untuk memberikan stimuli sebagai daya bujuk pesan yang dikomunikasikan kepada komunikan. Sebagai komunikasi yang paling lengkap dan paling sempurna, komunikasi antarpribadi berperan penting hingga kapanpun, selama manusia masih mempunyai emosi. Kenyataannya komunikasi tatap-muka ini membuat manusia merasa lebih akrab dengan sesamanya, berbeda dengan komunikasi lewat media massa seperti surat kabar, televisi, ataupun lewat teknologi tercanggih pun.

\section{Konteks Media Baru}


Kemajuan teknologi di bidang komunikasi dan informasi berkembang luar biasa dengan banyaknya penemuan-penemuan baru. Diawali dengan transistor, kemudian berkembang ke microchip system komunikasi satelit dan lain-lain. Perubahan terbesar di bidang komunikasi sejak munculnya televisi adalah penentuan dan pertumbuhan internet.

Dalam era terakhir media komunikasi interaktif dikenal sebagai media komputer. video text dan teletext, teleconferencing, TV kabel, dan sebagainya (Bungin, 2008: 113). Seiring berkembangnya teknologi dalam bidang komunikasi dan kebutuhan manusia agar bisa tetap berhubungan, meski dipisahkan jarak dan waktu, maka kemudian hal tersebut yang memicu lahirnya media baru. Perkembangan teknologi yang memicu lahirnya media baru tidak serta merta menghapuskan atau mengganti media lama. Ada beberapa karakteristik media lama yang tidak bisa digantikan oleh media baru. Hal ini bisa terjadi karena masyarakat dunia sekarang sudah memasuki sebuah tahapan ke dalam masyarakat informasi. Dalam masyarakat informasi, kebutuhan akan informasi menjadi kebutuhan yang sangat mutlak dimana informasi menjadi komoditas yang bernilai ekonomis dan bermakna strategis. Dengan pentingnya informasi maka masyarakat tak lagi menilai harga yang harus dibayarkan untuk bisa mengikuti perkembangan teknologi komunikasi

Saat ini, saluran media dicirikan dengan banyaknya pilihan yang membingungkanterdapat ratusan saluran televisi kabel dan program siaran sesuai permintaan yang dapat dijumpai setiap hari, belum lagi internet yang memiliki isi beraneka ragam tanpa batas. Selanjutnya dan mungkin yang lebih penting saat ini teknologi media baru memberi peluang bagi selera dan mengkreasi isi media seperti blog, halaman Facebook, portal dan catatan harian video Youtube. (Berger dkk, 2015; 381).

Menurut Denis McQuail dalam bukunya Teori Komunikasi Massa (2011:43) ciri utama media baru adalah adanya saling keterhubungan, aksesnya terhadap khalayak individu sebagai penerima maupun pengirim pesan, interaktivitasnya, kegunaan yang beragam sebagai karakter yang terbuka, dan sifatnya yang ada di mana-mana. Adapun perbedaan media baru dari media lama, yakni media baru mengabaikan batasan percetakan dan model penyiaran dengan memungkinakan terjadinya percakapan antar banyak pihak, memungkinkan penerimaan secara simultan, perubahan dan penyebaran kembali objekobjek budaya, mengganngu tindakan komunikasi dari posisi pentingnya dari hubungan kewilayahn dan modernitas, menyediakan kontak global secara instan, dan memasukkan subjek modern/akhir modern ke dalam mesin aparat yang berjaringan.

Komunikasi yang diperantai komputer (computer-mediated communication) berbeda dengan penggunaan media lain karena sifatnya sementara, multimodal dengan sedikit penggunaan kode perilaku pengaturan, dan memungkinkan "memanipulasi" konten (McQuail, 2011:158)

\section{Media Sosial}

Secara sederhana, istilah media bisa dijelaskan sebagai alat komunikasi sebagaimana defenisi yang selama ini diketahui. Terkadang media ini cenderung lebih dekat terhadap sifatnya yang massa karena terlihat dari berbagai teori yang muncul dalam komunikasi massa. Kata sosial dalam media sosial secara teori semestinya didekati oleh ranah sosiologi. Kata sosial secara sederhana merujuk pada relasi sosial. Relasi sosial itu sendiri bias dilihat dalam kategori aksi sosial dan relasi sosial.

Dua pengertian dasar tentang media dan sosial telah dijelaskan, namun tidak mudah membuat sebuah defenisi tetang media sosial berdasarkan perangkat teknologi semata. Diperlukan pedekatan teori-teori sosial yang memperjelas apa yang membedakan antara 
media sosial dan media lainnya di internet sebelum pada kesimpulan apa yang dimaksud dengan media sosial.

Media Sosial adalah medium di internet yang memungkinkan pengguna merepresentasikan dirinya maupun berinteraksi, bekerjasama, berbagi, berkomunikasi dengan pengguna lain, dan membentuk ikatan sosial secara virtual. (Rulli Nasrullah, 2015:13). Media sosial adalah jaringan informasi baru dan teknologi informasi dengan menggunakan suatu bentuk komunikasi menggunakan konten interaktif dan userdiproduksi, dan hubungan interpersonal diciptakan dan dipelihara.

Setidaknya lima fitur utama yang mudah untuk mengidentifikasi (1) jaringan sosial dan.interaksi sosial, (2) partisipasi, (3) penggunaan penyedia yang berbeda (misalnya mesin pencari, ruang blog, dll), (4) keterbukaan, dan (5) kolaborasi (antara pengguna dan kelompok pengguna) (Eysenbach, 2008)

\section{Facebook}

Facebook adalah situs jejaring sosial (social networking) atau disebut juga layanan jaringan sosial secara online, yang memungkinkan penggunanya saling berinteraksi dan berbagi informasi di seluruh dunia (Arifin, 2009:30). Menurut Saputra (2004) Facebook adalah website jaringan sosial dimana para pengguna dapat bergabung dalam komunitas seperti kota, kerja, sekolah, dan daerah untuk melakukan hubungan dan berinteraksi dengan orang lain. Orang juga dapat menambahkan teman-teman mereka, mengirim pesan, dan memperbarui profil pribadi agar orang lain dapat melihat tentang dirinya.

Facebook adalah sebuah situs web jejaring sosial populer yang diluncurkan pada 4 Februari 2004. FB didirikan oleh Mark Zuckerberg seorang mahasiswa Harvard kelahiran 14 Mei 1984 dan mantan murid Ardsley HighSchool. Pada awal awal kuliahnya situs web jejaring sosial ini, kenanggotaannya masih dibbatasi untuk mahasiswa dari Harvard College.

Terdapat sejumlah kelebihan fasilitas ataupun fitur yang dimiliki Facebook dibanding program media sosial lannyayang dapat digunakan dan dinikmati oleh para penggunanya, yaitu :

1. Umumnya data profil di riil karena sebagai personal pressrelease dan meningkatkan jaringan pertemanan. Baik itu teman baruatau teman lama, di dalam atau pun di luar negeri, serta baik yangsudah dikenal ataupun teman baru.

2. Updating data dapat dilakukan dengan mudah, bisa melalui personal compueter $(P C)$, laptop, smartphone yang terhubung dengan internet dan handphone.

3. Tag atau penamaan yang saling terhubung untuk foto-foto, sehingga bisa menjadi awal untuk saling berkomunikasi dengan teman-teman lama. Fasilitas ini bisa menjadi salah satu kunci penting yang memungkinkan facebook menjadi ajang reuni atau mencari teman lama dimana pun berada.

4. Pengorganisasian kegiatan updating lebih mudah karena ada pemberitahuan (notifikasi) tentang banyak hal sehingga mudah untuk mengetahui tambahan reaksi teman-teman sejak $\log$ in yang terakhir. Notifikasi ini misalnya ada teman yang menyetujui menjadi teman, teman yang menulis pesan.

5. Notifikasi atau alert (pemberitahuan sesaat) dapat juga dilihat dialamat $e$-mail yang terdaftar.

6. Dimungkinkan juga untuk chatting satu orang dengan satu orang dan chatting secara bersama-sama.

7. Bisa membuat grup sesuai dengan keinginan, sehingga memudahkan untuk mengelompokkan rekan sesuai dengan klasifikasi tertentu. 
8. Terdapat penelitian pada dinding yaitu menuliskan pesan ke publik ke teman yang memungkinkan untuk memberikan nilai positif atau teman tertentu.

9. Dapat mengirim pesan secara terbatas. Terdapat tiga kategori pengiriman pesan yaitu kirim ke satu orang, kirim ke semua anggota grup, kirim khusus untuk admin dan kirim ke kelompok rekan-rekan.

10. Memungkinkan untuk melihat acara yang akan dihadiri dan teman yang akan ulang tahun, pada menu events dan brithdays.

11. Layanan selling (penjualan/penawaran barang atau jasa) yang diperbolehkan antar user.

12. Layanan mobile acsess, yakni layanan untuk mobile dengan feature bisa melalui short messages system (SMS) (Rusman, dkk. 2011:407)

\section{Remaja}

Menurut Peaget (dalam Hurlock, 2004:206) bahwa masa remaja adalah dimana ketika mereka berada pada masa adolescence. Awal masa remaja bermula dari usia 13 tahun sampai 16 atau 17 tahun, dan akhir masa remaja bermula dari usia 16 atau 17 tahun sampai 18 tahun. Dalam usia ini terjadi proses kematangan mental, emosional, sosial dan fisik.Pada masa ini terjadi masa peralihan dari masa kanak-kanak menuju ke masa dewasa yang meliputi perubahan biologik, perubahan psikologik dan perubahan sosial.

Menurut Sri Rumini \& Siti Sundari (2004: 53) masa remaja adalah peralihan dari masa anak dengan masa dewasa yang mengalami perkembangan semua aspek/ fungsi untuk memasuki masa dewasa. Masa remaja berlangsung antara umur 12 tahun sampai dengan 21 tahun bagi wanita dan 13 tahun sampai dengan 22 tahun bagi pria. Sedangkan menurut Zakiah Darajat (1990: 23) remaja adalah masa peralihan diantara masa kanakkanak dan dewasa. Dalam masa ini anak mengalami masa pertumbuhan dan masa perkembangan fisiknya maupun perkembangan psikisnya. Mereka bukanlah -anak baik bentuk badan ataupun cara berfikir atau bertindak, tetapi bukan pula orang dewasa yang telah matang.

Hal senada diungkapkan oleh Santrock (2003: 26) bahwa remaja (adolescene) diartikan sebagai masa perkembangan transisi antara masa anak dan masa dewasa yang mencakup perubahan biologis, kognitif, dan sosial-emosional. Batas usia remaja yang umum digunakan oleh para ahli adalah antara 12 hingga 21 tahun. Rentang waktu usia remaja ini biasanya dibedakan atas tiga, yaitu $12-15$ tahun = masa remaja awal, $15-18$ tahun $=$ masa remaja pertengahan, dan $18-21$ tahun $=$ masa remaja akhir. Tetapi Monks, Knoers, dan Haditono membedakan masa remaja menjadi empat bagian, yaitu masa praremaja $10-12$ tahun, masa remaja awal $12-15$ tahun, masa remaja pertengahan $15-18$ tahun, dan masa remaja akhir 18 - 21 tahun (Deswita, 2006: 192)

Definisi yang dipaparkan oleh Sri Rumini \& Siti Sundari, Zakiah Darajat, dan Santrock tersebut menggambarkan bahwa masa remaja adalah masa peralihan dari masa anak-anak dengan masa dewasa dengan rentang usia antara 12-22 tahun, dimana pada masa tersebut terjadi proses pematangan baik itu pematangan fisik, maupun psikologis.

\section{Teori S-O-R}

Teori S-O-R adalah singkatan dari Stimulus-Organism-Response merupakan proses komunikasi yang menimbulkan reaksi khusus, sehingga seseorang dapat mengharapkan dan memperkirakan kesesuaian antara pesan dan reaksi komunikan. Unsur-unsur pada model ini adalah pesan (Stimulus), komunikan (Organism), dan efek (Response) (Effendy, 2003: 254). 
Effendy (2003:225) menjelaskan, bahwa pada awalnya teori ini berasal dari psikologi, kalau kemudian menjadi teori komunikasi tidaklah mengherankan, karena objek material dari psikologi dan ilmu komunikasi adalah sama, yaitu manuisa yang jiwanya meliputi komponen-komonen : sikap, opini, perilaku, kognisi, afektif dan konasi. Prinsip teori ini sebenarnya merupakan prinsip yang sederhana, yaitu respon merupakan reaksi balik dari individu ketika menerima stimuli dari media.

Menurut model ini, organism menghasilkan perilaku tertentu jika ada kondisi stimulus tertentu pula, efek yang ditimbulkan adalah reaksi khusus terhadap stimulus khusus, sehingga seseorang dapat mengharapkan dan memperkirakan kesesuaian antara pesan dan reaksi komunikan. Asumsi dasar dari model ini adalah : media massa menimbulkan efek yang terarah, segera dan langsung terhadap komunikan. Stimulus Response Theory atau S-R theory. Model ini menunjukkan bahwa komunikasi merupakan proses aksi-reaksi. Artinya model ini mengasumsi bahwa kata-kata verbal, isyarat non verbal, simbol-simbol tertentu akan merangsang orang lain memberikan respon dengan cara tertentu. Pola S-O-R ini dapat berlangsung secara positif atau negatif;misal jika orang tersenyum akan dibalas tersenyum ini merupakan reaksi positif, namun jika tersenyum dibalas dengan palingan muka maka ini merupakan reaksi negatif.

Model inilah yang kemudian mempengaruhi suatu teori klasik komunikasi yaitu Hypodermic needle atau teori jarum suntik. Asumsi dari teori inipun tidak jauh berbeda dengan model S-O-R, yakni bahwa media secara langsung dan cepat memiliki efek yang kuat terhadap komunikan. Artinya media diibaratkan sebagai jarum suntik besar yang memiliki kapasitas sebagai perangsang (S) dan menghasilkan tanggapan (R) yang kuat pula.

Respons atau perubahan sikap bergantung pada proses terhadap individu. Stimulus yang merupakan pesan yang disampaikan kepada komunikan dapat diterima atau ditolak, komunikasi yang terjadi dapat berjalan apabila komunikan memberikan perhatian terhadap stimulus yang disampaikan kepadanya. Sampai pada proses komunikan tersebut memikirkannya sehingga timbul pengertian dan penerimaan atau mungkin sebaliknya. Perubahan sikap dapat terjadi berupa perubahan kognitif, afektif atau behavioral. 


\section{Metode}

Jenis penelitian yang digunakan adalah metode dengan pendekatan kuantitatif. Penelitian kuantitatif merupakan "penelitian dengan meneliti seberapa besar pengaruh variabel bebas (independent) terhadap variabel terikat (dependent)" (Sugiono, 2006:11). Penyajian data dalam penelitian kuantitatif adalah berupa angka-angka dan menggunakan analisa statistik biasanya bertujuan untuk menunjukkan hubungan antara variabel, menguji teori dan mencari generalisasi yang mempunyai nilai prediksi (Sugiono, 2006:11).

Metode penelitian kuantitatif yang digunakan adalah metode penelitian korelasional untuk meneliti pada populasi atau sampel tertentu. Pengumpulan data menggunakan instrumen penelitian, analisis data bersifat kuantitatif/statistik dengan tujuan untuk menguji hipotesis yang telah ditetapkan.Variabel-variabel yang digunakan untuk mengetahui pengaruh yang bersifat sebab akibat (kausal) antara variabel independen dengan variabel dependen ini ialah dengan proses penganalisaan data yang berupa data kuantitatif. Adapun hipotesa atau jawaban sementara dari penelitian ini adalah: 1. Tidak ada pengaruh penggunaan media sosial Facebook terhadap perilaku komunikasi siswa Madrash Tsanawiyah Aisyiyah Sumatera Utara. 2. Ada pengaruh penggunaan media sosial Facebook terhadap perilaku komunikasi siswa Madrasah Tsanawiyah Aisyiyah Sumatera Utara.

Populasi dalam penelitian adalah siswa Madrasah Tsanawiyah Aisyiyah yang duduk di kelas VII, VIII dan IX serta aktif menggunakan Facebook. Dari keseluruhan siswa berjumlah 216 orang (sumber: Arsip Sekolah), sedangkan yang aktif menggunakan Facebook sebanyak 155 (sumber : Data Peneliti). Dari populasi yang berjumlah 155 siswa, dikarenakan jumlah populasi yang diambil dalam penelitian ini lebih dari 100 orang, maka penelitian ini mengambil sebagian yang menjadi sampel sebagai responden. Untuk mendapatkan jumlah sampel penelitian, peneliti menggunakan rumus Slovin yang dijelaskan oleh Sugiyono (2011:87). Adapun rumus Slovin yang dimaksud adalah :

$$
\eta=\frac{\mathbf{N}}{\mathbf{1}+\mathbf{N}(\mathbf{e})^{2}}
$$

Keterangan :

$\mathrm{n}:$ Jumlah Sampel

$\mathrm{N}$ : Jumlah Populasi

e : Batas kesalahan yang ditoleransi (peneliti mengambil kesalahan $10 \%$ atau 0,1 )

Berdasarkan rumus di atas, maka untuk menentukan jumlah sampel dari data keseluruhan populasi adalah sebagai berikut :

$$
\left.\mathbf{n}=\frac{\mathbf{N}}{1+\mathbf{N}(\mathbf{e})^{2}}=\frac{155}{1+155(0,1)^{2}}=\frac{155}{\mathbf{2 , 5 5}}=60,78 \text { (digenapkan menjadi } 61\right)
$$

Untuk itu, jumlah sampel pada penelitian ini adalah sebanyak 61 siswa. Guna menyeleksi sampel yang berjumlah 61 dari populasi yang berjumlah 155 siswa, peneliti menggunakan teknik Sampling Purposive. Sampling Purposive adalah teknik penentuan sampel dengan pertimbangan tertentu. (Sugiyono, 2011:84). Pertimbangan yang dimaksud adalah pemilihan sampel berdasarkan durasi siswa dalam menggunakan media sosial Facebook. Peneliti menggunakan angket atau kuesioner dan diukur dengan skala likert yang digunakan untuk mengukur sikap, pendapat, dan persepsi seseorang atau sekelompok 
orang tentang fenomena sosial yang telah ditetapkan secara spesifik oleh peneliti yang disebut sebagai variabel penelitian (Sugiyono,2011:93). Dalam penelitian ini menggunakan empat alternatif jawaban, yaitu : "Sangat Setuju", "Setuju", "Kurang Setuju" dan "Tidak Setuju". Skor jawaban mempunyai nilai antara 1 (satu) sampai 4 (empat). Untuk menguji validitas tiap item instrument adalah dengan mengkorelasikan antara skor-skor tiap item dengan skor total keseluruhan instrument. Item dikatakan valid, jika " $\mathrm{r}_{\text {hit }}>\mathrm{r}$ tab" dan sebaliknya (Sudijono, 1987:190). Untuk mengetahui validitas instrument pada penelitian ini, digunakan program SPSS 21.0 forwindows. Selanjutnya dilakuka uji reliabilitas adalah uji derajat ketepatan, ketelitian atau keakuratan yang ditunjukkan oleh instrumen pengukuran. Butir Kuesioner dikatakan reliable (handal) apabila jawaban seseorang terhadap kuesioner adalah konsisten. Penentuan kuesioner reliable (handal) dengan menggunakan alpha cronbach $>0,60$ dan tidak reliable (handal) jika sama dengan atau dibawah 0,60 (Sunyoto, 2013:114). Ada dua tahap dalam menganalisis data yaitu pengujian persyaratan analisis dan pengujian hipotesis. Sesuai dengan jenis penelitian ini, maka sebelum teknik statistik yang digunakan untuk menguji hipotesis diterapkan, terlebih dahulu data dideskripsikan dengan mengungkapkan mean, median, modus, dan standar deviasi, juga disajikan daftar distribusi frekuensi dan histogram. Sebelum dilakukan pengujian hipotesis, terlebih dahulu dilakukan uji normalitas dan uji multikolinieritas. Tingkat signifikan ditentukan dengan $\alpha=5 \%$. Perlu diketahui bahwa besaran yang sering digunakan dalam penelitian non eksakta untuk menentukan taraf nyata adalah $1 \%, 5 \%$, 10\% (Sanusi, 2003:54). Untuk mengetahui kebenaran hipotesis didasarkan pada ketentuan sebagai berikut:

- $\mathrm{H}_{\mathrm{o}}$ ditolak dan $\mathrm{H}_{\mathrm{a}}$ diterima jika thitung $>$ ttabel atau jika $\mathrm{t}_{\mathrm{sig}}<\alpha$

- $\mathrm{H}_{\mathrm{o}}$ diterima dan $\mathrm{H}_{\mathrm{a}}$ ditolak jika thitung $<\mathrm{t}$ tabel atau jika $\mathrm{t}_{\text {sig }}>\alpha$

a. Uji F

Uji $\mathrm{F}$ dilakukan untuk mengetahui ada tidaknya pengaruh variabel bebas secara bersama-sama terhadap variabel terikat. Formulasi hipotesis:

$\mathrm{H}_{\mathrm{O}}: \mathrm{b}_{1}, \mathrm{~b}_{2}, \mathrm{~b}_{3}=0$ : artinya variabel bebas secara bersama-sama tidak mempunyai pengaruh yang signifikan terhadap variabel terikat.

$\mathrm{H}_{\mathrm{a}}: \mathrm{b}_{1}, \mathrm{~b}_{2}, \mathrm{~b}_{3} \neq 0$ : artinya variabel bebas secara bersama-sama mempunyai pengaruh yang signifikan terhadap variabel terikat.

Untuk menguji kebenaran hipotesis alternatif dilakuakan uji $\mathrm{F}$ dengan rumus sebagai berikut:

$$
F_{h}=\frac{\frac{R^{2}}{k}}{\frac{1-R^{2}}{\eta-k-1}}
$$

\footnotetext{
Keterangan:

$\mathrm{R}=$ Koefisien korelasi ganda

$\mathrm{K}=$ Jumlah variabel independen.
} 
Penelitian ini dilaksanakan di Kompleks sekolah Madrasah Tsanawiyah Aisyiyah yang beralamat di Jalan Mesjid No. 806 Desa Bandar Khalipah Kecamatan Percut Sei Tuan Kabupaten Deli Serdang, Provinsi Sumatera Utara. Lokasi sekolah ini berada $12 \mathrm{~km}$ dan memiliki jarak tempuh \pm 20 menit melalui jalan lintas Medan-Batang Kuis dari pusat kota Medan ke arah timur laut.

Sekolah Tsanawiyah yang satu-satunya dimiliki oleh Pimpinan Wilayah Aisyiyah Sumatera ini berdiri sejak tahun 2002, memiliki dua gedung sekolah dan salah satu gedungnya berlantai dua dengan satu ruang guru dan enam ruang kelas. Jumlah siswa yang terdaftar bersekolah disana adalah sebanyak 216 siswa dengan rincian kelas VII sebanyak 76 siswa, kelas VIII sebanyak 79 dan kelas IX sebanyak 61 siswa (Sumber : Arsip Sekolah). Waktu Penelitian dilaksanakan sejak bulan Juli hingga September 2019. 


\section{Hasil dan Pembahasan}

Setelah kuesioner yang berisikan 11 pertanyaan pada variabel X (facebook) dan pada variabel Y (perilaku komunikasi), disusun kemudian disebar kepada responden yang menjadi objek penelitian ini yaitu siswa Madrasah Tsanawiyah Aisyiyah Wilayah Sumatera utara yang berjumlah 61 orang. Agar penyebaran angket bisa merata dan bisa merepresentasikan jawaban dari seluruh siswa yang aktif menggunakan facebook, maka cara yang digunakan peneliti adalah membagi jumlah sampel dengan pembagian yang mewakili kelas masing-masing. Berdasarkan hasil kuesioner yang telah disebar, didapatkan hasil tabulasi data sebagai berikut :

Tabel 3

Karakteristik Responden Berdasarkan Jenis Kelamin

\begin{tabular}{|c|c|c|c|}
\hline No & Jenis Kelamin & Frekwensi & Persentasi \\
\hline 1 & Laki-Laki & 27 & 44,26 \\
\hline 2 & Perempuan & 34 & 55,74 \\
\hline & Total & $\mathbf{6 1}$ & $\mathbf{1 0 0 , 0}$ \\
\hline
\end{tabular}

Sumber : Kuesioner Penelitian (2019)

Berdasarkan keterangan tabel 3, dapat dilihat bahwa dari jenis kelamin, responden penelitian ini lebih didominasi oleh siswa perempuan yaitu sebanyak 34 orang atau 55,74 $\%$,. Sedangkan selebihnya sebanyak 27 orang atau 44, $26 \%$ adalah siswa berjenis kelamin laki-laki.

Tabel 4

Karakteristik Responden Berdasarkan Kelas

\begin{tabular}{|c|c|c|c|}
\hline No & Kelas & Frekwensi & Persentasi \\
\hline 1 & IX & 25 & 40,98 \\
\hline 2 & VIII & 25 & 40,98 \\
\hline 3 & VII & 11 & 18,04 \\
\hline & Total & $\mathbf{6 1}$ & $\mathbf{1 0 0 , 0}$ \\
\hline
\end{tabular}

Sumber : Kuesioner Penelitian (2019)

Berdasarkan tabel 4, hasil tabulasi data dapat dilihat bahwa jumlah responden yang duduk di kelas IX (sembilan) dan kelas VIII (delapan) adalah sama yaitu berjumlah 25 orang atau 40,98\%. Sedangkan yang duduk dikelas VII (tujuh) adalah sebanyak 11 orang atau $18,04 \%$.

Tabel 5

Karakteristik Responden Berdasarkan Usia

\begin{tabular}{|c|c|c|c|}
\hline No & Usia & Frekwensi & Persentasi \\
\hline 1 & 11 Tahun & 1 & 1,64 \\
\hline 2 & 12 Tahun & 13 & 21,31 \\
\hline 3 & 13 Tahun & 15 & 24,59 \\
\hline
\end{tabular}


Vol 2 No. 2, 2019, 11-44

DOI: https://doi.org/10.30596/persepsi.v2i2.3940

\begin{tabular}{|c|c|c|c|}
\hline 4 & 14 Tahun & 24 & 39,34 \\
\hline 5 & 15 Tahun & 6 & 9,84 \\
\hline 6 & 16 Tahun & 2 & 3,28 \\
\hline & Total & $\mathbf{6 1}$ & $\mathbf{1 0 0 , 0}$ \\
\hline
\end{tabular}

Sumber : Kuesioner Penelitian (2019)

Tabel 5, menunjukkan bahwa dari segi usia, responden yang paling banyak adalah siswa yang berusia 14 tahun yaitu sebanyak 24 orang atau 39,34\%. Kemudian sebanyak 15 orang atau $24,59 \%$, adalah siswa yang berusia 13 tahun, lalu sebanyak 13 orang $(21,31 \%)$ siswa berusia 12 tahun, 6 orang $(9,84 \%)$ berusia 15 tahun, 2 orang $(3,28 \%)$ berusia 16 tahun dan 1 orang atau $1,64 \%$ adalah siswa yang berusia 11 tahun.

Hasil yang diperoleh dari responden berdasarkan jawaban atas pertanyaan yang diberikan untuk mengetahui pengaruh facebook dan youtube terhadap perilaku komunikasi siswa Madrasah Tsanawiyah Aisyiyah Wilayah Sumatera Utara, kemudian dideskripsikan dan dicocokkan dengan tabel penentuan kategori setiap variabel yang dimaksud. Adapun deskriptif persentase jawaban pertanyaan dari masing-masing sub variabel adalah sebagai berikut :

a) Variabel Facebook

Deskriptif persentasi dari hasil jawaban atas pertanyaan berdasarkan indikator dari variabel facebook, dapat dilihat dari tabel-tabel berikut :

Tabel 6

Dalam Satu Hari Berapa Sering Dalam Sehari Anda Membuka Facebook

\begin{tabular}{|c|c|c|c|}
\hline No & Alternatif Jawaban & Frekwensi & Persentasi \\
\hline 1 & Tidak Sering & 8 & 13,1 \\
\hline 2 & Kurang Sering & 21 & 34,4 \\
\hline 3 & Sering & 18 & 29,5 \\
\hline 4 & Sangat Sering & 14 & 23,0 \\
\hline \multicolumn{2}{|c|}{ Total } & $\mathbf{6 1}$ & $\mathbf{1 0 0 , 0}$ \\
\hline
\end{tabular}

Sumber : Kuesioner Penelitian No.1 (2019)

Tabel 6 menumjukkan bahwa jawaban responden ketika ditanya berapa sering dalam satu hari mereka membuka facebook, dari 61 orang yang terbanyak dari mereka yaitu sebesar 21 orang atau 34,4\% menjawab kurang sering, sedangkan 18 orang (23\%) menjawa sering. Kemudian 14 orang atau $23,0 \%$ menjawab sangat sering dan yang menjawab tidak sering hanya 8 orang atau $13,1 \%$. Selisih yang tidak terlalu jauh antara jawaban terbanyak yaitu kurang sering (21 orang) dan sering (18) yang hanya berjarak 3 angka, bahkan jika ditambah jawaban sangat sering (14 orang), maka dapat disimpulkan bahwa kebanyakan siswa tersebut cukup sering membuka Facebook.

Tabel 7

Berapa Lama Waktu Yang Anda Gunakan Ketika Menggunakan Facebook 


\begin{tabular}{|c|c|c|c|}
\hline No & Alternatif Jawaban & Frekwensi & Persentasi \\
\hline 1 & Dibawah 1 Jam & 24 & 39,3 \\
\hline 2 & 1 Sampai 3 Jam & 18 & 29,5 \\
\hline 3 & 3 Sampai 5 Jam & 11 & 18,1 \\
\hline 4 & Lebih Dari 5 Jam & 8 & 13,1 \\
\hline \multicolumn{2}{|c|}{ Total } & $\mathbf{6 1}$ & $\mathbf{1 0 0 , 0}$ \\
\hline
\end{tabular}

Sumber : Kuesioner Penelitian No.2 (2019)

Berdasarkan tabel 7, dapat dijelaskan bahwa lama waktu yang digunakan oleh siswa ketika menggunakan Facebook, dari 61 orang paling banyak menjawab kurang dari 1 jam, yaitu sebanyak 24 orang atau 39,3\%. Kemudian yang menjawab antara 1 sampai 3 jam adalah sebanyak 18 orang $(29,5 \%)$, lalu sebanyak 11 orang $(18,1 \%)$ menjawab antara 3 sampai 5 jam dan yang terakhir sebanyak 8 orang $(13,1)$ menggunakan facebook lebih dari 5 jam. Berdasarkan jawaban responden tersebut, diketahui bahwa mereka menggunakan Facebook memerlukan durasi waktu yang sedikit dan tidak lama, akan tetapi dengan frekwensi yang sering.

Tabel 8

Anda Mengetahui Facebook Bukan Dengan Sendirinya, Melainkan Melalui Teman Atau Media Lain

\begin{tabular}{|c|c|c|c|}
\hline No & Alternatif Jawaban & Frekwensi & Persentasi \\
\hline 1 & Tidak Setuju & 16 & 26,2 \\
\hline 2 & Kurang Setuju & 7 & 11,5 \\
\hline 3 & Setuju & 22 & 36,1 \\
\hline 4 & Sangat Setuju & 16 & 26,2 \\
\hline \multicolumn{2}{r}{ Total } & $\mathbf{6 1}$ & $\mathbf{1 0 0 , 0}$ \\
\hline
\end{tabular}

Sumber : Kuesioner Penelitian No.3 (2019)

Berdasarkan tabel 8, dapat diketahui bahwa jawaban responden atas pertanyaan tentang apakah mereka mengetahui Facebook melalui teman atau media lain, bukan tahu dengan sendirinya, maka kebanyakan mereka menjawab setuju yaitu sebesar $36 \%$ atau sebanyak 22 orang. Sedangkan yang menjawab tidak setuju dan sangat setuju memiliki jumlah yang sama banyak yaitu 16 orang atau $26,2 \%$, selebihnya 7 orang atau $11,5 \%$ mejawab kurang setuju. Hal tersebut dapat diartikan kebanyakan mereka mengetahui Facebook melalui ajakan teman atau informasi yang mereka dapat dari media lain, misal televisi, radio, ataupun media cetak. Bisa dikatakan mereka menggunakan Facebook karena ikut teman atau mengikuti tren. 
Tabel 9

Fitur Menulis Status Dan Komentar Di Facebook Sangat Menarik

\begin{tabular}{|c|c|c|c|}
\hline No & Alternatif Jawaban & Frekwensi & Persentasi \\
\hline 1 & Tidak Setuju & 10 & 16,4 \\
\hline 2 & Kurang Setuju & 11 & 18,0 \\
\hline 3 & Setuju & 24 & 39,3 \\
\hline 4 & Sangat Setuju & 16 & 26,2 \\
\hline \multicolumn{2}{r}{ Total } & $\mathbf{6 1}$ & $\mathbf{1 0 0 , 0}$ \\
\hline
\end{tabular}

Sumber : Kuesioner Penelitian No.4 (2019)

Berdasarkan distribusi jawaban responden tentang apakah fitur menulis status atau kolom komentar yang ada di facebook sangat menarik yang terdapat pada tabel 9, maka diketahui dari 61 responden yang paling banyak mereka menjawab setuju yaitu sebanyak 24 orang atau 39,3\%. Kemudian yang menjawab sangat setuju sebanyak 16 orang $(26,2)$, yang menjawab kurang setuju sebanyak 11 orang $(18,0 \%)$ dan yang menjawab tidak setuju sebanyak 10 orang atau 16,4\%. Hal tersebut berarti kebanyakan para siswa menganggap bahwa fitur menulis status dan komentar yang ada pada facebook menarik dan mereka menyukainya.

Tabel 10

Fitur Chatting Atau Ngobrol, Berkirim Pesan Di Facebook Sangat Menarik

\begin{tabular}{|c|c|c|c|}
\hline No & Alternatif Jawaban & Frekwensi & Persentasi \\
\hline 1 & Tidak Setuju & 8 & 13,1 \\
\hline 2 & Kurang Setuju & 4 & 6,6 \\
\hline 3 & Setuju & 29 & 47,5 \\
\hline 4 & Sangat Setuju & 20 & 32,8 \\
\hline \multicolumn{2}{r}{ Total } & $\mathbf{6 1}$ & $\mathbf{1 0 0 , 0}$ \\
\hline
\end{tabular}

Sumber : Kuesioner Penelitian No.5 (2019)

Berdasarkan distribusi jawaban responden tentang apakah fitur chatting atau ngobrol, berkirim pesan yang ada di Facebook yang terdapat pada tabel 10, maka diketahui dari 61 siswa yang paling banyak menjawab setuju yaitu sebanyak 29 orang atau 47,5\%. Kemudian yang menjawab sangat setuju sebanyak 20 orang $(32,8 \%)$, lalu yang menjawab tidak setuju sebanyak 8 orang $(13,1 \%)$ dan yang menjawab kurang setuju 4 orang atau 6,6\%. Hal tersebut berarti kebanyakan para siswa menganggap bahwa fitur chatting berkirim pesan yang ada pada Facebook menarik dan mereka menyukainya.

Tabel 11

Fitur Grup Facebook Sangat Menarik

\begin{tabular}{|c|c|c|c|}
\hline No & Alternatif Jawaban & Frekwensi & Persentasi \\
\hline 1 & Tidak Setuju & 13 & 21,3 \\
\hline 2 & Kurang Setuju & 9 & 14,8 \\
\hline
\end{tabular}


Vol 2 No. 2, 2019, 11-44

DOI: https://doi.org/10.30596/persepsi.v2i2.3940

\begin{tabular}{|c|c|c|c|}
\hline 3 & Setuju & 23 & 37,7 \\
\hline 4 & Sangat Setuju & 16 & 26,2 \\
\hline \multicolumn{2}{|c|}{ Total } & $\mathbf{6 1}$ & $\mathbf{1 0 0 , 0}$ \\
\hline
\end{tabular}

Sumber : Kuesioner Penelitian No.6 (2019)

Berdasarkan distribusi jawaban responden tentang apakah fitur grup yang ada di Facebook sangat menarik yang terdapat pada tabel 11, diketahui dari 61 siswa yang paling banyak menjawab setuju yaitu sebanyak 23 orang atau 37,7\%. Kemudian yang menjawab sangat setuju sebanyak 16 orang $(26,2 \%)$, lalu yang menjawab tidak setuju sebanyak 13 orang $(21,3 \%)$ dan yang menjawab kurang setuju sebanyak 9 orang atau 14,8\%. Hal tersebut berarti kebanyakan para siswa menganggap bahwa fitur grup yang ada pada Facebook menarik dan mereka menyukainya.

Tabel 12

Fitur Unggah Dan Unduh Video Atau Foto Di Facebook Sangat Menarik

\begin{tabular}{|c|c|c|c|}
\hline No & Alternatif Jawaban & Frekwensi & Persentasi \\
\hline 1 & Tidak Setuju & 8 & 13,1 \\
\hline 2 & Kurang Setuju & 11 & 18,0 \\
\hline 3 & Setuju & 25 & 41,0 \\
\hline 4 & Sangat Setuju & 17 & 27,9 \\
\hline \multicolumn{2}{r}{ Total } & $\mathbf{6 1}$ & $\mathbf{1 0 0 , 0}$ \\
\hline
\end{tabular}

Sumber : Kuesioner Penelitian No.7 (2019)

Berdasarkan distribusi jawaban responden tentang apakah fitur unggah dan unduh video atau foto yang ada di Facebook yang terdapat pada tabel 12 sangat menarik. Diketahui dari 61 siswa yang paling banyak menjawab setuju yaitu sebanyak 25 orang atau $41,0 \%$. Kemudian yang menjawab sangat setuju sebanyak 17 orang $(27,9 \%)$, lalu yang menjawab kurang setuju sebanyak 11 orang $(18,0 \%)$ dan yang menjawab kurang setuju sebanyak 8 orang atau $13,1 \%$. Hal tersebut berarti kebanyakan para siswa menganggap bahwa fitur unggah dan unduh video atau foto yang ada pada facebook menarik dan mereka menyukainya.

Tabel 13

Saya Menyukai Membaca Status Teman Atau Idola Saya Di Facebook

\begin{tabular}{|c|c|c|c|}
\hline No & Alternatif Jawaban & Frekwensi & Persentasi \\
\hline 1 & Tidak Setuju & 9 & 14,8 \\
\hline 2 & Kurang Setuju & 11 & 18,0 \\
\hline 3 & Setuju & 19 & 31,1 \\
\hline 4 & Sangat Setuju & 22 & 36,1 \\
\hline \multicolumn{2}{r}{ Total } & $\mathbf{6 1}$ & $\mathbf{1 0 0 , 0}$ \\
\hline
\end{tabular}

Sumber : Kuesioner Penelitian No.8 (2019)

Berdasarkan tabel 13, distribusi jawaban responden tentang menyukai membaca status teman atau idola mereka di Facebook tersebut, diketahui bahwa dari 61 siswa, sebanyak 22 orang atau 36,1\% menjawab sangat setuju. Sedangkan yang menjawab setuju 
yaitu sebanyak 19 orang atau 31,1\%, dan yang menjawab kurang setuju sebanyak 11 orang $(18,0 \%)$, sisanya sebanyak 9 orang $(14,8 \%)$ menjawab tidak setuju. Itu berarti aktifitas mereka saat menggunakan Facebook adalah membaca status Facebook teman dan idola mereka.

Tabel 14

Dalam Membaca Atau Berkirim Status Di Facebook Saya Selalu Memilih Yang Baik

\begin{tabular}{|c|c|c|c|}
\hline No & Alternatif Jawaban & Frekwensi & Persentasi \\
\hline 1 & Tidak Setuju & 1 & 1,6 \\
\hline 2 & Kurang Setuju & 3 & 4,9 \\
\hline 3 & Setuju & 20 & 32,8 \\
\hline 4 & Sangat Setuju & 37 & 60,7 \\
\hline \multicolumn{2}{|r|}{ Total } & 61 & 100,0 \\
\hline
\end{tabular}

Sumber : Kuesioner Penelitian No.9 (2019)

Dilihat dari tabel 14, dapat dijelaskan bahwa dari 61 orang responden, sebanyak 37 orang atau $60,7 \%$ menjawab sangat setuju bahwa dalam membaca atau berkirim status di Facebook mereka selalu memilih yang baik. Kemudian yang menjawab setuju yaitu sebanyak 20 orang atau 32,8\%, sedangkan yang menjawab kurang setuju yaitu sebanyak 3 orang $(4,9)$ dan yang menjawab tidak setuju hanya 1 orang atau $1,6 \%$. Hal tersebut bearti bahwa para siswa dalam menggunakan Facebook mereka tidak sembarangan memilih atau melihat konten yang ada akan tetapi sereka terlebih dahuu menyeleksinya dan hanya memilih yang baik bagi mereka.

Tabel 15

Ketika Menggunakan Facebook Saya Selalu Mendapat Sesuatu Hal Dan Pengalaman Yang Baru

\begin{tabular}{|c|c|c|c|}
\hline No & Alternatif Jawaban & Frekwensi & Persentasi \\
\hline 1 & Tidak Setuju & 7 & 11,5 \\
\hline 2 & Kurang Setuju & 6 & 9,8 \\
\hline 3 & Setuju & 25 & 41,0 \\
\hline 4 & Sangat Setuju & 23 & 37,7 \\
\hline \multicolumn{2}{r}{ Total } & $\mathbf{6 1}$ & $\mathbf{1 0 0 , 0}$ \\
\hline
\end{tabular}

Sumber : Kuesioner Penelitian No.10 (2019)

Tabel 15, menunjukkan bahwa dari 61 responden, sebanyak 25 orang atau 41,0\%, paling banyak mereka menjawab setuju bahwa ketika menggunakan facebook mereka selalu mendapatkan sesuatu hal dan pengalaman yang baru dan 23 orang $(37,7 \%)$ yang memilih sangat setuju, sedangkan yang memilih tidak setuju 7 orang $(11,5 \%)$ dan yang memilih kurang setuju adalah 6 orang atau 9,8\%. 
Vol 2 No. 2, 2019, 11-44

DOI: https://doi.org/10.30596/persepsi.v2i2.3940

Dengan Menggunakan Facebook, Saya Tetap Selalu Terhubung Oleh Kerabat Dan Teman

\begin{tabular}{|c|c|c|c|}
\hline No & Alternatif Jawaban & Frekwensi & Persentasi \\
\hline 1 & Tidak Setuju & 3 & 4,9 \\
\hline 2 & Kurang Setuju & 4 & 6,6 \\
\hline 3 & Setuju & 14 & 23,0 \\
\hline 4 & Sangat Setuju & 40 & 65,6 \\
\hline \multicolumn{2}{r}{ Total } & $\mathbf{6 1}$ & $\mathbf{1 0 0 , 0}$ \\
\hline
\end{tabular}

Sumber : Kuesioner Penelitian No.11 (2019)

Berdasarkan tabulasi tabel 16, dapat dilihat bahwa dari 61 responden, sebanyak 40 orang atau 65,6\%, atau lebih dari separuhnya memilih sangat setuju bahwa dengan menggunakan Facebook, mereka bisa selalu tetap terhubung oleh kerabat dan teman mereka. Sebanyak 14 orang atau $23,0 \%$ menjawab setuju, sedangkan yang menjawab kurang setuju sebanyak 4 orang $(6,6 \%)$ dan yang menjawab tidak setuju hanya 3 orang atau $4,9 \%$ Menurut penjelasan di atas, dapat disimpulkan bahwa kebanyakan responden merasa bisa selalu tetap terhubung dengan teman atau kerabat mereka dengan menggunakan Facebook. Hal itu sesuai dengan fungsi Facebook sebagai jaringan yang dapat menghubungkan seseorang dengan orang lain dari satu tempat dengan tempat lain dari seluruh dunia.

Tabel 17

Anda Mengetahui Facebook Bukan Dengan Sendirinya, Melainkan Melalui Teman Atau Media Lain

\begin{tabular}{|c|c|c|c|}
\hline No & Alternatif Jawaban & Frekwensi & Persentasi \\
\hline 1 & Tidak Setuju & 11 & 18,0 \\
\hline 2 & Kurang Setuju & 12 & 19,7 \\
\hline 3 & Setuju & 18 & 29,5 \\
\hline 4 & Sangat Setuju & 20 & 32,8 \\
\hline \multicolumn{2}{|c|}{ Total } & $\mathbf{6 1}$ & $\mathbf{1 0 0 , 0}$ \\
\hline
\end{tabular}

Sumber : Kuesioner Penelitian No.12 (2019)

Berdasarkan tabel 19 di atas, dapat diketahui bahwa jawaban responden atas pertanyaan tentang apakah mereka mengetahui Facebook melalui teman atau media lain, bukan tahu dengan sendirinya, maka kebanyakan mereka menjawab sangat setuju yaitu sebesar 32,8\% atau sebanyak 20 orang. Kemudian selanjutnya yang memilih setuju yaitu sebanyak 18 orang atau $29,5 \%$, dan yang memilih kurang setuju sebanyak 12 orang $(19,7 \%)$ dan yang terakhir sebanyak 11 orang atau $18,0 \%$ yang memilih tidak setuju. Dari penjelasan tersebut dapat disimpulkan bahwa sebagian besar siswa mngetahui aplikasi Facebook melalui informasi yang mereka dapat dari teman ataupun media lainnya, televisi, spanduk dan media lainnya. 
b) Variabel Perilaku Komunikasi

Deskriptif persentasi dari hasil jawaban atas pertanyaan berdasarkan indikator dari variabel perilaku komunikasi, dapat dilihat dari tabel-tabel berikut:

Tabel 18

Ketika Menggunakan Facebook, Saya Selalu Mencari Sesuatu Yang Baru Dengan Melakukan Interaksi Dengan Teman, Ataupun Orang Lain

\begin{tabular}{|c|c|c|c|}
\hline No & Alternatif Jawaban & Frekwensi & Persentasi \\
\hline 1 & Tidak Setuju & 7 & 11,5 \\
\hline 2 & Kurang Setuju & 9 & 14,8 \\
\hline 3 & Setuju & 24 & 39,3 \\
\hline 4 & Sangat Setuju & 21 & 34,4 \\
\hline \multicolumn{2}{|r|}{ Total } & 61 & 100,0 \\
\hline
\end{tabular}

Sumber : Kuesioner Penelitian No.13 (2019)

Berdasarkan tabel 18, hasil jawaban responden tentang pernyataan bahwa menggunakan Facebook mereka selalu mencari hal baru dengan melakukan interaksi kepada teman ataupun orang lain di Facebook dapat dilihat bahwa dari 61 siswa, paling banyak mereka menjawab setuju yaitu sebanyak 24 orang atau 39,3\%, kemudian yang menjawab sangat setuju sebanyak 21 orang atau 34,4\%, sedangkan yang menjawab kurang setuju sebanyak 9 orang $(14,8 \%)$ dan yang menjawab tidak setuju hanya 7 orang atau sebesar $11,5 \%$. Kesimpulan dari penjelasan jawaban kuesioner di atas adalah para siswa menggunakan Facebook dan berinteraksi dengan orang lain di kedua media sosial itu karena ingin mendapatkan hal baru, pengalaman baru dan juga kosa kata baru, yang membuat mereka merasa tidak ketinggalan zaman.

Tabel 19

Ketika Menggunakan Facebook, Saya Selalu Ingin Mendapatkan Respons, Maka Dari Itu Saya Selalu Aktif Menulis Status Atau Berkomentar

\begin{tabular}{|c|c|c|c|}
\hline No & Alternatif Jawaban & Frekwensi & Persentasi \\
\hline 1 & Tidak Setuju & 13 & 21,3 \\
\hline 2 & Kurang Setuju & 22 & 36,1 \\
\hline 3 & Setuju & 15 & 24,6 \\
\hline 4 & Sangat Setuju & 11 & 18,0 \\
\hline \multicolumn{2}{r}{ Total } & $\mathbf{6 1}$ & $\mathbf{1 0 0 , 0}$ \\
\hline
\end{tabular}

Sumber : Kuesioner Penelitian No.14 (2019)

Berdasarkan hasil jawaban responden tentang pernyataan bahwa menggunakan Facebook mereka selalu ingin mendapatkan respons, makanya mereka aktif menulis status atau berkomentar dan melakukan interaksi kepada teman ataupun orang lain di Facebook berdasarkan tabel 29, dapat dilihat bahwa dari 61 siswa, paling banyak mereka menjawab kurang setuju yaitu sebanyak 22 orang atau 36,1\%, kemudian yang menjawab setuju sebanyak 15 orang atau $24,6 \%$. Siswa yang menjawab tidak setuju sebanyak 13 orang $(21,3 \%)$ dan yang menjawab sangat setuju hanya 7 orang atau sebesar $11,5 \%$. Kesimpulan 
dari penjelasan jawaban kuesioner diatas adalah bahwa para siswa menggunakan Facebook tidak selalu ingin mendapatkan respons, akan tetapi hanya sekedar membuat status dan berkomentar tanpa peduli mendapatkan tanggapan dari teman ataupun orang lain.

Tabel 20

Menggunakan Facebook, Saya Selalu Ingin Mendapatkan Informasi Dan Pengetahuan

\begin{tabular}{|c|c|c|c|}
\hline No & Alternatif Jawaban & Frekwensi & Persentasi \\
\hline 1 & Tidak Setuju & 3 & 4,9 \\
\hline 2 & Kurang Setuju & 4 & 6,6 \\
\hline 3 & Setuju & 21 & 34,4 \\
\hline 4 & Sangat Setuju & 33 & 54,1 \\
\hline \multicolumn{2}{r}{ Total } & $\mathbf{6 1}$ & $\mathbf{1 0 0 , 0}$ \\
\hline
\end{tabular}

Sumber : Kuesioner Penelitian No.15 (2019)

Dari hasil jawaban responden tentang pernyataan bahwa mereka menggunakan Facebook adalah karena ingin mendapatkan informasi dan pengetahuan, berdasarkan tabel 30, dapat dilihat bahwa dari 61 siswa, mereka lebih banyak yang menjawab sangat setuju yaitu sebanyak 33 orang atau $54,1 \%$, kemudian yang menjawab setuju sebanyak 21 orang atau $34,4 \%$, sedangkan yang menjawab kurang setuju hanya 4 orang $(6,6 \%)$ dan yang menjawab tidak setuju hanya 3 orang atau sebesar 4,9\%.Kesimpulan dari penjelasan jawaban kuesioner di atas adalah bahwa para siswa menggunakan Facebook dan karena ingin menambah ilmu pengetahuan dan informasi. Dalam status yang dibagikan di Facebook banyak yang berisi tentang pelajaran dan juga informasi tentang kejadian yang ada di sekitar kita.

Tabel 21

Saya Selalu Mendahulukan Sesuatu Yang Membuat Rasa Aman Ketika Berinteraksi Dengan Orang Melalui Facebook

\begin{tabular}{|c|c|c|c|}
\hline No & Alternatif Jawaban & Frekwensi & Persentasi \\
\hline 1 & Tidak Setuju & 5 & 8,2 \\
\hline 2 & Kurang Setuju & 13 & 21,3 \\
\hline 3 & Setuju & 27 & 44,3 \\
\hline 4 & Sangat Setuju & 16 & 26,2 \\
\hline \multicolumn{2}{r}{ Total } & $\mathbf{6 1}$ & $\mathbf{1 0 0 , 0}$ \\
\hline
\end{tabular}

Sumber : Kuesioner Penelitian No.16 (2019)

Tabel 21, hasil jawaban responden tentang pernyataan bahwa menggunakan Facebook mereka selalu mendahulukan sesuatu yang membuat rasa aman ketika melakukan interaksi kepada teman ataupun orang lain di Facebook, berdasarkan tabel tersebut, dapat dilihat bahwa dari 61 siswa, yang paling banyak yaitu jawaban setuju sebanyak 27 orang atau 44,3\%, kemudian yang menjawab sangat setuju sebanyak 16 orang atau $26,2 \%$. Sedangkan yang menjawab kurang setuju sebanyak 13 orang $(21,3 \%)$ dan yang menjawab tidak setuju hanya 5 orang atau sebesar $8,2 \%$. Kesimpulan dari penjelasan jawaban kuesioner diatas adalah bahwa kebanyakan para siswa ketika menggunakan 
Facebook lebih mendahulukan rasa aman ketika berinteraksi dengan seseorang di kedua media sosial tersebut. Rasa aman tentu sangat diperlukan oleh seseorang terutama ketika berhubungan dengan orang luar yang belum pernah kita kenal sebelumnya.

Tabel 22

Ketika Melakukan Komunikasi Melalui Facebook, Saya Selalu Ingin Kelihatan Pintar Dan Lebih Dari Yang Lain

\begin{tabular}{|c|c|c|c|}
\hline No & Alternatif Jawaban & Frekwensi & Persentasi \\
\hline 1 & Tidak Setuju & 10 & 16,4 \\
\hline 2 & Kurang Setuju & 14 & 23,0 \\
\hline 3 & Setuju & 23 & 37,7 \\
\hline 4 & Sangat Setuju & 14 & 23,0 \\
\hline \multicolumn{2}{r}{ Total } & $\mathbf{6 1}$ & $\mathbf{1 0 0 , 0}$ \\
\hline
\end{tabular}

Sumber : Kuesioner Penelitian No.17 (2019)

Berdasarkan tabel 22, distribusi hasil jawaban responden tentang pernyataan ketika melakukan komunikasi di Facebook, mereka selalu ingin kelihatan pintar dan lebih dari yang lain, dapat dilihat bahwa dari 61 siswa, paling banyak mereka menjawab setuju yaitu sebanyak 23 orang atau $37,7 \%$, kemudian yang menjawab sangat setuju dan kurang setuju memiliki jumlah yang sama yaitu sebanyak 14 orang atau $23,0 \%$. Sedangkan yang menjawab tidak setuju 9 orang atau sebesar 16,4\%.Kesimpulan dari penjelasan jawaban kuesioner di atas adalah terlihat bahwa para siswa ketika berkomunikasi di-Facebook, mereka ingin selalu terlihat lebih dari orang lain dalam hal pengetahuan. Oleh sebab itu mereka mencoba menggunakan kata-kata yang menunjukkan segi intelektualitas mereka

Tabel 23

Saat Melakukan Interaksi Dengan Seseorang Di Facebook, Saya Selalu Ingin Menang Dan Menguasai Suasana

\begin{tabular}{|c|c|c|c|}
\hline No & Alternatif Jawaban & Frekwensi & Persentasi \\
\hline 1 & Tidak Setuju & 26 & 42,6 \\
\hline 2 & Kurang Setuju & 18 & 29,5 \\
\hline 3 & Setuju & 11 & 18,0 \\
\hline 4 & Sangat Setuju & 6 & 9,8 \\
\hline \multicolumn{2}{r}{ Total } & $\mathbf{6 1}$ & $\mathbf{1 0 0 , 0}$ \\
\hline
\end{tabular}

Sumber : Kuesioner Penelitian No.18 (2019)

Berdasarkan tabel 23, jawaban responden tentang pernyataan bahwa ketika melakukan interaksi di Facebook, mereka selalu ingin menang dan menguasai suasana, dapat dilihat bahwa dari 61 siswa, paling banyak yaitu 26 orang atau sebesar 42,6\% mereka menjawab tidak setuju dan sebanyak 18 orang atau 29,5\% menjawab kurang setuju. Sedangkan yang menjawab setuju sebanyak 11 orang orang $(18,0 \%)$ dan yang menjawab sangat setuju hanya 6 orang atau sebesar 9,8\%. Dari penjelasan jawaban kuesioner diatas dapat disimpulkan bahwa para siswa ketika berinteraksi dengan orang lain 
di Facebook tidak selalu ingin menang dan menguasai suasana. Karena menurut mereka menggunakan Facebook adalah untuk bersenang-senang bukan mencari musuh.

Tabel 24

Ketika melakukan Interaksi Di Facebook, Tak Harus Mengikuti Norma Dan Etika

\begin{tabular}{|c|c|c|c|}
\hline No & Alternatif Jawaban & Frekwensi & Persentasi \\
\hline 1 & Tidak Setuju & 24 & 39,3 \\
\hline 2 & Kurang Setuju & 19 & 31,1 \\
\hline 3 & Setuju & 13 & 21,3 \\
\hline 4 & Sangat Setuju & 5 & 8,2 \\
\hline \multicolumn{2}{|r|}{ Total } & 61 & 100,0 \\
\hline
\end{tabular}

Sumber : Kuesioner Penelitian No.19 (2019)

Berdasarkan table 24 hasil jawaban responden tentang pernyataan bahwa ketika berinteraksi di Facebook tidak harus mengikuti norma dan etika di atas, dapat dilihat bahwa dari 61 siswa, yang paling banyak yaitu jawaban tidak setuju sebanyak 24 orang atau 39,3\%, kemudian yang menjawab kurang setuju sebanyak 19 orang atau $31,1 \%$. Sedangkan yang menjawab setuju sebanyak 13 orang $(21,3 \%)$ dan yang menjawab sangat setuju hanya 5 orang atau sebesar 8,2\%.Kesimpulan dari penjelasan jawaban kuesioner bahwa meskipun Facebook bukanlah dunia nyata, namun tetap perlu mengedepankan etika dan moral ketika berinteraksi dengan orang lain di media sosial tersebut. Etika dan moral yang baik akan mendatangkan kawan yang baik, sedangkan etika dan moral yang buruk akan mendatangkan musuh.

Tabel 25

Ketika Menggunakan Facebook, Saya Sering Merasa Terlalu Emosi, Misalnya Marah, Sedih

\begin{tabular}{|c|c|c|c|}
\hline No & Alternatif Jawaban & Frekwensi & Persentasi \\
\hline 1 & Tidak Setuju & 13 & 21,3 \\
\hline 2 & Kurang Setuju & 22 & 36,1 \\
\hline 3 & Setuju & 15 & 24,6 \\
\hline 4 & Sangat Setuju & 11 & 18,0 \\
\hline \multicolumn{2}{r}{ Total } & $\mathbf{6 1}$ & $\mathbf{1 0 0 , 0}$ \\
\hline
\end{tabular}

Sumber : Kuesioner Penelitian No.20 (2019)

Berdasarkan hasil jawaban responden tentang pernyataan bahwa menggunakan Facebook, mereka sering merasa terlalu emosional, misalnya sedih atau marah, berdasarkan tabel 35, dapat dilihat bahwa dari 61 siswa, yang paling banyak yaitu jawaban kurang setuju sebanyak 22 orang atau 36,1\%, kemudian jawaban kedua yaitu setuju sebanyak 15 orang atau 24,6\%. Selanjutnya siswa yang menjawab tidak setuju 13 orang $(21,3 \%)$ dan yang menjawab tidak setuju 11 orang atau sebesar $18,0 \%$. Kesimpulan dari penjelasan jawaban kuesioner di atas adalah bahwa kebanyakan para siswa ketika menggunakan Facebook tidak terlalu mengikutkan emosi saat berinteraksi. Namun tidak sdikit juga yang terlalu emosional ketika berselancar di dunia maya, terutama Facebook. 
Tabel 26

Saat Melakukan Interaksi Di Facebook, Saya Sering Merespon Dengan Spontan Tanpa Difikir Terlebih Dahulu

\begin{tabular}{|c|c|c|c|}
\hline No & Alternatif Jawaban & Frekwensi & Persentasi \\
\hline 1 & Tidak Setuju & 20 & 32,8 \\
\hline 2 & Kurang Setuju & 18 & 29,5 \\
\hline 3 & Setuju & 12 & 19,7 \\
\hline 4 & Sangat Setuju & 11 & 18,0 \\
\hline \multicolumn{2}{r}{ Total } & $\mathbf{6 1}$ & $\mathbf{1 0 0 , 0}$ \\
\hline
\end{tabular}

Sumber : Kuesioner Penelitian No.21 (2019)

Berdasarkan tabel 26 jawaban responden tentang pernyataan bahwa ketika melakukan interaksi di Facebook, mereka sering merespon dengan spontan tanpa difikir terlebih dahulu, dapat dilihat bahwa dari 61 siswa, paling banyak yaitu 20 orang atau sebesar $32,8 \%$ mereka menjawab tidak setuju dan sebanyak 18 orang atau $29,5 \%$ menjawab kurang setuju, sedangkan yang menjawab setuju sebanyak 12 orang atau 19,7\% dan yang menjawab sangat setuju sebanyak 11 orang orang atau 18,0\%. Dari penjelasan jawaban kuesioner diatas dapat disimpulkan bahwa para siswa ketika berinteraksi dengan orang lain di Facebook mereka selalu merespon dengan sesuatu yang terlebih dahulu difikirkan dan dipertimbangkan. Agar respons yang mereka berikan lebih terarah dan tidak menimbulkan permusuhan.

Tabel 27

Dalam Menggunakan Facebook, Saya Selalu Menjaga Rasa Saling Percaya

\begin{tabular}{|c|c|c|c|}
\hline No & Alternatif Jawaban & Frekwensi & Persentasi \\
\hline 1 & Tidak Setuju & 7 & 11,5 \\
\hline 2 & Kurang Setuju & 17 & 27,9 \\
\hline 3 & Setuju & 23 & 37,7 \\
\hline 4 & Sangat Setuju & 14 & 23,0 \\
\hline \multicolumn{2}{r}{ Total } & $\mathbf{6 1}$ & $\mathbf{1 0 0 , 0}$ \\
\hline
\end{tabular}

Sumber : Kuesioner Penelitian No.22 (2019)

Dari tabel 27, hasil jawaban responden tentang pernyataan bahwa dalam menggunakan Facebook, mereka selalu menjaga rasa saling percaya, dapat dilihat bahwa dari 61 siswa, yang paling banyak yaitu 23 orang atau 37,7\% siswa yang menjawab setuju, kemudian jawaban selanjutnya yaitu kurang setuju sebanyak 17 orang atau 27,9\%. Sedangkan yang menjawab sangat setuju sebanyak 14 orang $(23,0 \%)$ dan yang menjawab tidak setuju hanya 7 orang atau sebesar $11,5 \%$. Kesimpulan dari penjelasan jawaban kuesioner diatas adalah bahwa ketika melakukan interaksi dengan teman atau seseorang di Facebook, para siswa merasa perlu membangun rasa saling percaya (trust). Karena tanpa rasa percaya maka tidak akan ada jaminan keamanan dan kenyamanan. 
Tabel 28

Ketika Melakukan Komunikasi Di Facebook, Saya Selalu Memiliki Tujuan Dan Ingin Mendapatkan Apa Yang Saya Inginkan

\begin{tabular}{|c|c|c|c|}
\hline No & Alternatif Jawaban & Frekwensi & Persentasi \\
\hline 1 & Tidak Setuju & 11 & 18,0 \\
\hline 2 & Kurang Setuju & 13 & 21,3 \\
\hline 3 & Setuju & 25 & 41,0 \\
\hline 4 & Sangat Setuju & 12 & 19,7 \\
\hline \multicolumn{2}{|c|}{ Total } & $\mathbf{6 1}$ & $\mathbf{1 0 0 , 0}$ \\
\hline
\end{tabular}

Sumber : Kuesioner Penelitian No.21 (2019)

Menurut hasil jawaban responden tentang pernyataan bahwa ketika berkomunikasi di- Facebook, mereka memiliki tujuan dan ingin mendapatkan apa yang mereka inginkan, berdasarkan tabel 38, dapat dilihat bahwa dari 61 siswa, yang paling banyak siswa menjawabsetuju yaitu 25 orang atau $41,0 \%$, kemudian yang menjawab kurang setuju sebanyak 13 orang atau 21,3\%. Sedangkan yang menjawab sangat setuju sebanyak 12 orang $(19,7 \%)$ dan yang menjawab tidak setuju sebesar 11 orang atau sebesar $18,0 \%$. Kesimpulan dari penjelasan jawaban kuesioner diatas adalah bahwa ketika berinteraksi dan berkomunikasi di Facebook, kebanyakan siswa memiliki tujuan tertentu, yang mana tujuan tertentu selalu ingin mereka capai. Tujuan ini bisa tentang informasi, pengetahuan ataupun tentang emosi.

Seperti diketahui, nilai "r tabel" untuk responden $(\mathrm{N})$ sebanyak 61 dengan nilai signifikansi 5\% adalah 0,248, maka adapun hasil hitungan data menggunakan SPSS, didapatkan sebagai berikut :

a. Data Variabel X1 (Facebook)

Tabel 29

Uji Validitas Kuesioner (Facebook)

\begin{tabular}{|c|c|c|c|c|}
\hline No. & Item Kuesioner & Keterangan & Hasil & Validitas \\
\hline \multirow{3}{*}{1} & \multirow{3}{*}{ X1.1 } & $\begin{array}{l}\text { Pearson } \\
\text { Correlation } \\
\end{array}$ &, $693^{* *}$ & \multirow[t]{3}{*}{ Valid } \\
\hline & & Sig. (2-tailed) & ,000 & \\
\hline & & $\mathrm{N}$ & 61 & \\
\hline \multirow{3}{*}{2} & \multirow{3}{*}{$\mathrm{X} 1.2$} & $\begin{array}{l}\text { Pearson } \\
\text { Correlation }\end{array}$ &, $645^{* *}$ & \multirow[t]{3}{*}{ Valid } \\
\hline & & Sig. (2-tailed) &, 000 & \\
\hline & & $\mathrm{N}$ & 61 & \\
\hline \multirow{3}{*}{3} & \multirow{3}{*}{$\mathrm{X} 1.3$} & $\begin{array}{l}\text { Pearson } \\
\text { Correlation }\end{array}$ &, $305^{*}$ & \multirow[t]{3}{*}{ Valid } \\
\hline & & Sig. (2-tailed) & ,017 & \\
\hline & & $\mathrm{N}$ & 61 & \\
\hline
\end{tabular}


Vol 2 No. 2, 2019, 11-44

DOI: https://doi.org/10.30596/persepsi.v2i2.3940

\begin{tabular}{|c|c|c|c|c|}
\hline \multirow{3}{*}{4} & \multirow{3}{*}{ X1.4 } & $\begin{array}{l}\text { Pearson } \\
\text { Correlation }\end{array}$ &, $756^{* *}$ & \multirow[t]{3}{*}{ Valid } \\
\hline & & Sig. (2-tailed) &, 000 & \\
\hline & & $\mathrm{N}$ & 61 & \\
\hline \multirow{3}{*}{5} & \multirow{3}{*}{$\mathrm{X} 1.5$} & $\begin{array}{l}\text { Pearson } \\
\text { Correlation }\end{array}$ &, $558^{* *}$ & \multirow{3}{*}{ Valid } \\
\hline & & Sig. (2-tailed) &, 000 & \\
\hline & & $\mathrm{N}$ & 61 & \\
\hline \multirow{3}{*}{6} & \multirow{3}{*}{ X1.6 } & $\begin{array}{l}\text { Pearson } \\
\text { Correlation }\end{array}$ &, $541^{* *}$ & \multirow[t]{3}{*}{ Valid } \\
\hline & & Sig. (2-tailed) & ,000 & \\
\hline & & $\mathrm{N}$ & 61 & \\
\hline \multirow{3}{*}{7} & \multirow{3}{*}{$\mathrm{X} 1.7$} & $\begin{array}{l}\text { Pearson } \\
\text { Correlation }\end{array}$ &, $654^{* *}$ & \multirow[t]{3}{*}{ Valid } \\
\hline & & Sig. (2-tailed) &, 000 & \\
\hline & & $\mathrm{N}$ & 61 & \\
\hline \multirow{3}{*}{8} & \multirow{3}{*}{$\mathrm{X} 1.8$} & $\begin{array}{l}\text { Pearson } \\
\text { Correlation }\end{array}$ &, $632^{* *}$ & \multirow[t]{3}{*}{ Valid } \\
\hline & & Sig. (2-tailed) & ,000 & \\
\hline & & $\mathrm{N}$ & 61 & \\
\hline \multirow{3}{*}{9} & \multirow{3}{*}{ X1.9 } & $\begin{array}{l}\text { Pearson } \\
\text { Correlation }\end{array}$ &, $280^{*}$ & \multirow[t]{3}{*}{ Valid } \\
\hline & & Sig. (2-tailed) & ,029 & \\
\hline & & $\mathrm{N}$ & 61 & \\
\hline \multirow{3}{*}{10} & \multirow{3}{*}{$\mathrm{X} 1.10$} & $\begin{array}{l}\text { Pearson } \\
\text { Correlation }\end{array}$ &, $518^{* *}$ & \multirow[t]{3}{*}{ Valid } \\
\hline & & Sig. (2-tailed) &, 000 & \\
\hline & & $\mathrm{N}$ & 61 & \\
\hline \multirow{3}{*}{11} & \multirow{3}{*}{$\mathrm{X} 1.11$} & $\begin{array}{l}\text { Pearson } \\
\text { Correlation }\end{array}$ &, $484^{* *}$ & \multirow[t]{3}{*}{ Valid } \\
\hline & & Sig. (2-tailed) & ,000 & \\
\hline & & $\mathrm{N}$ & 61 & \\
\hline & & & & \\
\hline
\end{tabular}

Sumber: data olahan penelitian (2019)

b. Data Variabel Y (Perilaku Komunikasi)

Tabel 30

Uji Validitas Kuesioner Y (Perilaku Komunikasi)

\begin{tabular}{|l|l|l|l|l|}
\hline No. & Item Kuesioner & Keterangan & Hasil & Validitas \\
\hline
\end{tabular}


Vol 2 No. 2, 2019, 11-44

DOI: https://doi.org/10.30596/persepsi.v2i2.3940

\begin{tabular}{|c|c|c|c|c|}
\hline \multirow{3}{*}{1} & \multirow{3}{*}{ Y.1 } & $\begin{array}{l}\text { Pearson } \\
\text { Correlation }\end{array}$ &, $734^{* *}$ & \multirow[t]{3}{*}{ Valid } \\
\hline & & Sig. (2-tailed) &, 000 & \\
\hline & & $\mathrm{N}$ & 61 & \\
\hline \multirow{3}{*}{2} & \multirow{3}{*}{ Y.2 } & $\begin{array}{l}\text { Pearson } \\
\text { Correlation }\end{array}$ &, $528^{* *}$ & \multirow[t]{3}{*}{ Valid } \\
\hline & & Sig. (2-tailed) &, 000 & \\
\hline & & $\mathrm{N}$ & 61 & \\
\hline \multirow{3}{*}{3} & \multirow{3}{*}{ Y.3 } & $\begin{array}{l}\text { Pearson } \\
\text { Correlation }\end{array}$ &, $505^{* *}$ & \multirow[t]{3}{*}{ Valid } \\
\hline & & Sig. (2-tailed) &, 000 & \\
\hline & & $\mathrm{N}$ & 61 & \\
\hline \multirow{3}{*}{4} & \multirow{3}{*}{ Y.4 } & $\begin{array}{l}\text { Pearson } \\
\text { Correlation }\end{array}$ &, $541^{* *}$ & \multirow[t]{3}{*}{ Valid } \\
\hline & & Sig. (2-tailed) &, 000 & \\
\hline & & $\mathrm{N}$ & 61 & \\
\hline \multirow{3}{*}{5} & \multirow{3}{*}{ Y.5 } & $\begin{array}{l}\text { Pearson } \\
\text { Correlation }\end{array}$ &, $687^{* *}$ & \multirow[t]{3}{*}{ Valid } \\
\hline & & Sig. (2-tailed) &, 000 & \\
\hline & & $\mathrm{N}$ & 61 & \\
\hline \multirow{3}{*}{6} & \multirow{3}{*}{ Y.6 } & $\begin{array}{l}\text { Pearson } \\
\text { Correlation }\end{array}$ &, $574^{* * *}$ & \multirow[t]{3}{*}{ Valid } \\
\hline & & Sig. (2-tailed) &, 000 & \\
\hline & & $\mathrm{N}$ & 61 & \\
\hline \multirow{3}{*}{7} & \multirow{3}{*}{ Y.7 } & $\begin{array}{l}\text { Pearson } \\
\text { Correlation }\end{array}$ &, $514^{* *}$ & \multirow[t]{3}{*}{ Valid } \\
\hline & & Sig. (2-tailed) &, 000 & \\
\hline & & $\mathrm{N}$ & 61 & \\
\hline \multirow{3}{*}{8} & \multirow{3}{*}{ Y.8 } & $\begin{array}{l}\text { Pearson } \\
\text { Correlation }\end{array}$ &, $642^{* * *}$ & \multirow[t]{3}{*}{ Valid } \\
\hline & & Sig. (2-tailed) &, 000 & \\
\hline & & $\mathrm{N}$ & 61 & \\
\hline \multirow{5}{*}{9} & \multirow{3}{*}{ Y.9 } & $\begin{array}{l}\text { Pearson } \\
\text { Correlation }\end{array}$ &, $501^{* *}$ & \multirow[t]{3}{*}{ Valid } \\
\hline & & Sig. (2-tailed) & ,000 & \\
\hline & & $\mathrm{N}$ & 61 & \\
\hline & \multirow[t]{2}{*}{ Y.10 } & $\begin{array}{l}\text { Pearson } \\
\text { Correlation }\end{array}$ &, $432^{* * *}$ & \multirow[t]{2}{*}{ Valid } \\
\hline & & Sig. (2-tailed) &, 001 & \\
\hline
\end{tabular}


Vol 2 No. 2, 2019, 11-44

DOI: https://doi.org/10.30596/persepsi.v2i2.3940

\begin{tabular}{|c|l|l|r|r|}
\hline 10 & & $\mathrm{~N}$ & 61 & \\
\hline \multirow{4}{*}{11} & \multirow{3}{*}{ Y.11 } & Pearson &, $581^{* *}$ & \multirow{2}{*}{ Valid } \\
& & Correlation & & \\
\cline { 3 - 4 } & & Sig. (2-tailed) &, 000 & \\
\cline { 3 - 4 } & & $\mathrm{N}$ & 61 & \\
\hline
\end{tabular}

Sumber : Data Olahan Penelitian (2019)

Setelah data dinyatakan valid, maka langkah selanjutnya adalah menguji reliabilitas. Uji reliabilitas dilakukan untuk menguji ketepatan, ketelitian dan keakuratan yang ditunjukkan oleh instrumen pengukuran. Penentuan kuesioner reliabel atau tidak dengan menggunakan rumus alpha cronbach>0,60, maka kuesioner dianggap reliabel (handal), tapi jika sama dengan atau $<0,60$, maka kuesioner dianggap tidak reliabel (Sunyoto, 2013)

Berdasarkan perhitungan dengan menggunakan SPSS, maka didapatkan hasil sebagai berikut :

a. Data Variabel (Facebook)

Tabel 31

Uji ReliabilitasPer/item Kuesioner X (Facebook)

\begin{tabular}{|c|l|c|c|}
\hline No. & Item Kuesioner & $\begin{array}{c}\text { Alpha } \\
\text { Cronbach }\end{array}$ & Reliabilitas \\
\hline 1 & $\mathrm{X} 1.1$ &, 737 & Reliabel \\
\hline 2 & $\mathrm{X} 1.2$ &, 745 & Reliabel \\
\hline 3 & $\mathrm{X} 1.3$ &, 797 & Reliabel \\
\hline 4 & $\mathrm{X} 1.4$ &, 727 & Reliabel \\
\hline 5 & $\mathrm{X} 1.5$ &, 756 & Reliabel \\
\hline 6 & $\mathrm{X} 1.6$ &, 761 & Reliabel \\
\hline 7 & $\mathrm{X} 1.7$ &, 743 & Reliabel \\
\hline 8 & $\mathrm{X} 1.8$ &, 747 & Reliabel \\
\hline 9 & $\mathrm{X} 1.9$ &, 779 & Reliabel \\
\hline 10 & $\mathrm{X} 1.10$ &, 762 & Reliabel \\
\hline 11 & $\mathrm{X} 1.11$ &, 763 & Reliabel \\
\hline
\end{tabular}

Sumber : Data Olahan Penelitian (2019) 
Tabel 32

Uji ReliabilitasKeseluruhan Kuesioner X (Facebook)

\begin{tabular}{|c|c|}
\hline Cronbach's Alpha & N of Items \\
\hline, 774 & 11 \\
\hline
\end{tabular}

Sumber : Data Olahan Penelitian (2019)

Berdasarkan hasil olahan data untuk kuesioner variabel X1 secara keseluruhan didapat hasil alpha cronbach 0,774 yang mana hasil tersebut lebih besar > dari 0,60, yang berarti kuesioner untuk variabel X1 dianggap reliable.

b. Data Variabel Y (Perilaku Komunikasi)

Tabel 33

Uji Reliabilitas Per/item Kuesioner Y(Perilaku Komunikasi)

\begin{tabular}{|c|l|c|c|}
\hline No. & Item Kuesioner & $\begin{array}{c}\text { Alpha } \\
\text { Cronbach }\end{array}$ & Reliabilitas \\
\hline 1 & Y.1 &, 750 & Reliabel \\
\hline 2 & Y.2 &, 779 & Reliabel \\
\hline 3 & Y.3 &, 778 & Reliabel \\
\hline 4 & Y.4 &, 775 & Reliabel \\
\hline 5 & Y.5 &, 756 & Reliabel \\
\hline 6 & Y.6 &, 772 & Reliabel \\
\hline 7 & Y.7 &, 779 & Reliabel \\
\hline 8 & Y.8 &, 763 & Reliabel \\
\hline 9 & Y.9 &, 785 & Reliabel \\
\hline 10 & Y.10 &, 788 & Reliabel \\
\hline 11 & Y.11 &, 771 & Reliabel \\
\hline
\end{tabular}

Sumber : Data Olahan Penelitian (2019)

Tabel 34

Uji Reliabilitas Keseluruhan

Kuesioner Y (Perilaku Komunikasi) 


\begin{tabular}{|c|c|}
\hline Cronbach's Alpha & N of Items \\
\hline, 789 & 11 \\
\hline
\end{tabular}

Sumber : Data Olahan Penelitian (2019)

Berdasarkan hasil olahan data untuk kuesioner variabel Y secara keseluruhan didapat hasil alpha cronbach 0,789 yang mana hasil tersebut lebih besar > dari 0,60, yang berarti kuesioner untuk variabel Y dianggap reliable.

Untuk mengetahui apakah data yang diperoleh terdistribusi atau tersebar secara normal, maka perlu dilakukan uji normalitas. Dalam pengujian normalitas dilakukan dengan menggunakan uji kolmogrov-smirnov. Adapaun hasil dari pengujian normalitas menggunakan SPSS adalah sebagai berikut :

Tabel 35

Uji Normalitas "One-Sample Kolmogorov-Smirnov Test”

\begin{tabular}{|c|c|c|}
\hline & & $\begin{array}{c}\text { Unstandardized } \\
\text { Residual } \\
\end{array}$ \\
\hline \multicolumn{2}{|l|}{$\mathrm{N}$} & 61 \\
\hline & Mean & $0 \mathrm{E}-7$ \\
\hline Normal Parameters ${ }^{\mathrm{a}, \mathrm{b}}$ & $\begin{array}{l}\text { Std. Deviation } \\
\text { Absolute }\end{array}$ & $\begin{array}{r}4,71631663 \\
, 059\end{array}$ \\
\hline $\begin{array}{l}\text { Most Extreme } \\
\text { Differences }\end{array}$ & Positive & ,059 \\
\hline $\begin{array}{l}\text { Kolmogorov-Smirnov Z } \\
\text { Asymp. Sig. (2-tailed) }\end{array}$ & Negative & $\begin{array}{r}-, 045 \\
, 460 \\
, 984\end{array}$ \\
\hline
\end{tabular}

Sumber : Data Olahan Penelitian (2019)

Cara mengetahui apakah data yang dimaksud telah terdistribusi normal adalah dengan melihat nilai signifikansinya. Jika nilai signifikansinya $>0,05$ maka data berdistribusi normal. Berdasarkan tabel di atas, diketahui bahwa nilai signifikansi yang diperoleh sebesar 0,984, dan nilai itu lebih besar dari 0,05, itu berarti terbukti bahwa data penelitian ini berdistribusi normal. Uji multikolinieritas dilakukan untuk mengetahui apakah terjadi interkorelasi (hubungan) antara variabel independen dalam hal ini $\mathrm{X}$ (facebook).Regresi yang dikatakan baik adalah jika tidak terjadi interkorelasi (tidak terjadi hubungan) antara variabel-variabel independen.

Cara mengetahui apakah terdapat interkorelasi antar variabel indepennden, dengan menggunakan aplikasi SPSS adalah dengan melihat nilai toleransinya atau dengan melihat nilai VIF, jika nilai tolerance lebih besar $>$ dari 0,10 maka tidak terjadi multikolinieritas, atau jika nilai VIF lebih kecil < dari 10,00 maka artinya tidak terjadi multikolinieritas.

Adapun hasil olahan data penelitian yang didapat setelah diuji multikolinieritas menggunakan aplikasi SPSS adalah sebagai berikut : 
Tabel 36

Uji Multikolinieritas

\begin{tabular}{|l|c|c|}
\hline \multirow{2}{*}{ Model } & \multicolumn{2}{|c|}{ Collinearity Statistics } \\
\cline { 2 - 3 } & Tolerance & VIF \\
\hline (Constant) & & \\
Facebook &, 692 & 1,446 \\
Youtube &, 692 & 1,446 \\
\hline
\end{tabular}

Sumber : Data Olahan Penelitian (2019)

Berdasarkan tabel 36, diketahui nilai toleransi pada variabel X (facebook) adalah sama, yaitu sebesar 0,692 dan nilai tersebut lebih besar dari 0,10, begitu juga bila dilihat nilai VIF kedua variabel independen juga sama yaitu sebesar 1,446, dan nilai tersebut lebih kecil dari 10,00, itu berati dapat dikatakan tidak terjadi gejala multikolinieritas terhadap variabel independen.

Kita analisis pengaruh dari setiap variabel berdasarkan nilai t hitung yang diperoleh dengan membandingkan-nya terhadap $\mathrm{t}$ tabel dengan $\mathrm{df}=\mathrm{n}-\mathrm{k}-1=61-3-1=57$. Maka diperoleh $\mathrm{t}$ tabel dengan sifnifikansi 0,05 sebesar 1,672. Untuk mengetahui apakah ada pengaruh masing masing variabel $\mathrm{X} 1$ atau X2 terhadap variabel $\mathrm{Y}$, maka harus diketahui bahwa jika $t$ hitung $>\mathrm{t}$ tabel atau nilai signifikansi $<0,05$, maka terdapat pengaruh antara variabel $\mathrm{X}$ terhadap $\mathrm{Y}$.

Berdasarkan tabel tersebut maka dapat dilihat bahwa nilai t hitung untuk variabel $\mathrm{X} 1$ adalah sebesar 2,89 dan nilai signifikansi sebesar 0,00, sedangkan variabel X2 didapat $\mathrm{t}$ hitung sebesar 3,061 dengan nilai signifikansi 0,00. Jika dilihat nilai t tabel untuk responden sebanyak 61 orang adalah 1,672 maka berdasarkan hasil yang didapat bahwa penggunaan media facebook berpengaruh terhadap perilaku komunikasi. Begitu juga dengan penggunaan media youtube juga berpengaruh terhadap perilaku komunikasi. Sehingga secara keseluruhan berdasarkan hasil yang didapatkan pengaruh setiap variabel bebas terhadap variabel terikat mempunyai pengaruh yang signifikan, baik secara umum maupun secara khusus. Dengan demikian hipotesa awal (Ha) yang menyatakan bahwa terdapat pengaruh antara variabel-variabel bebas secara individu (parsial) terhadap variabel terikat diterima sedangkan Ho ditolak. Selain itu juga berdasarkan tabel tersebut kita bisa membuat persamaan regresi yang terjadi. Adapun persamaan regresi yang diperoleh ialah $\mathrm{Y}=4,062+0,357 \mathrm{X} 1+0,430 \mathrm{X} 2$ atau $\mathrm{Y}=4,062+0,357$ Facebook. Untuk mengetahui apakah ada pengaruh secara bersama-sama (simultan) antara dua variabel bebas terhadap variabel terikat, maka dilakukan uji F. Berdasarkan olah data yang dilakukan dengan menggunakan program aplikasi SPSS, maka didapatkan hasil sebagai berikut : 
Tabel 37

Uji F "Correlation"

\begin{tabular}{|c|c|c|c|c|c|}
\hline Model & $\begin{array}{l}\text { Sum of } \\
\text { Squares }\end{array}$ & Df & $\begin{array}{l}\text { Mean } \\
\text { Square }\end{array}$ & $\mathrm{F}$ & Sig. \\
\hline Regression & 923,021 & 2 & 461,510 & 20,056 &, $000^{\mathrm{b}}$ \\
\hline Residual & 1334,619 & 58 & 23,011 & & \\
\hline Total & 2257,639 & 60 & & & \\
\hline
\end{tabular}

Berdasarkan hasil pada tabel 37 , dapat dilihat bahwa nilai $\mathrm{F}$ tabel dengan df1 ialah $=\mathrm{k}-1=3-1=2$ dan df2 ialah $\mathrm{n}-\mathrm{k}=61-3=58$. Sedangkan diketahui nilai $\mathrm{F}$ hitung sebesar 20,056 dan nilai signifikansi sebesar 0,000. Konsep dasar dari nilai hitung uji $\mathrm{F}$ adalah, jika nilai $\mathrm{F}$ hitung $>\mathrm{F}$ tabel atau nilai signifikansi $<0,05$, maka terdapat pengaruh $\mathrm{X} 1$ dan X2 secara simultan terhadap Y. Jika dilihat $\mathrm{F}$ tabel untuk responden sebanyak 61 Orang adalah 3,16, itu berarti 20,05 $>3,16$ dan nilai signifikansi $0,00<0,05$ maka hal ini menunjukkan bahwa terdapat pengaruh yang signifikan antara penggunaan media sosial facebook dan youtube terhadap perilaku komunikasi siswa madrasah tsanawiyah aisyiyah wilayah Sumatera utara.

Selanjutnya untuk mengetahui seberapa besar pengaruh yang disebabkan oleh variabel bebas terhadap variabel terikat, dapat dilihat dari tabel berikut :

Tabel 38

Koefisien Determinasi

\begin{tabular}{|l|r|r|r|c|}
\hline Model & \multicolumn{1}{|c|}{$\mathrm{R}$} & $\begin{array}{c}\mathrm{R} \\
\text { Square }\end{array}$ & $\begin{array}{c}\text { Adjusted } \\
\mathrm{R} \text { Square }\end{array}$ & $\begin{array}{c}\text { Std. Error } \\
\text { of the } \\
\text { Estimate }\end{array}$ \\
\hline 1 &, $639^{\mathrm{a}}$ &, 409 &, 388 & 4,79694 \\
\hline
\end{tabular}

Sumber : Data Olahan Penelitian (2019)

Dari tabel 38 diketahui hasi R square didapatkan sebesar 0,409, ini berarti bahwa besarnya hubungan atau pengaruh penggunaan media sosial facebook dan youtube secara bersama sama terhadap perilaku komunikasi ialah sebesar $40,9 \%$. Hal ini menunjukkan bahwa pengaruh yang terjadi antara variabel bebas yaitu penggunaan media sosial facebook dan youtube dengan variabel terikat yaitu perilaku komunikasi adalah pengaruh yang cukup kuat. Dengan demikian diketahui bahwa sumbangan ataupun kontribusi antara penggunaan media sosial facebook dan youtube terhadap perilaku komunikasi ialah sebesar 40,9\% sedangkan sisanya 59,1\% dipengaruhi oleh faktor lain. Dengan demikian maka keputusannya adalah $\mathrm{H}_{\mathrm{a}}$ diterima dan $\mathrm{H}_{\mathrm{o}}$ ditolak, artinya dugaan bahwa terdapat pengaruh yang signifikan antara penggunaan media sosial Facebook secara bersama-sama (simultan) terhadap perilaku komunikasi siswa Madrasah Tsanawiyah Aisyiyah Wilayah Sumatera Utara terbukti benar. 


\section{Kesimpulan}

Sebagaimana telah dijelaskan dan dipaparkan hasil penelitian dan pengolahan data tentang pengaruh penggunaan media sosial Facebook terhadap perilaku komunikasi siswa Madrasah Tsanawiyah Aisyiyah Wilayah Sumatera Utara, maka dapat disimpulkan beberapa hal berikut :

1. Berdasarkan hasil analisis data untuk pengaruh penggunaan media sosial Facebook terhadap perilaku komunikasi siswa, dapat dilihat bahwa nilai $\mathrm{t}$ hitung untuk variabel X1 adalah sebesar 2,89 dan nilai signifikansi sebesar 0,00. Jika dilihat nilai $\mathrm{t}$ tabel untuk responden sebanyak 61 orang adalah 1,672 maka berdasarkan hasil yang didapat bahwa penggunaan media sosial facebook berpengaruh terhadap perilaku komunikasi. Itu berarti bahwa hipotesis pertama (Ha) diterima dan Ho ditolak.

2. Setelah dilakukan uji $\mathrm{F}$, untuk mengetahui adakah pengaruh variabel $\mathrm{X}$ secara bersama-sama (simultan) terhadap variabel $\mathrm{Y}$, diapatkan nilai $\mathrm{F}$ hitung sebesar 20,05 dan nilai tersebut lebih besar dari nilai $F$ tabel yang sebesar 3,16, maka hal ini menunjukkan bahwa terdapat pengaruh yang signifikan antara penggunaan media sosial Facebook terhadap perilaku komunikasi siswa madrasah tsanawiyah aisyiyah wilayah sumatera utara. Artinya hipotesa $(\mathrm{Ha})$ yang menyatakan ada pengaruh penggunaan media sosial facebook dan youtube terhadap perilaku komunikasi siswa Madrasah Tsanawiyah Wilayah Sumatera Utara diterima dan hipotesa yang menyatakan tidak ada pengaruh (Ho) ditolak.

3. Hasil perhitungan didapatkan nilai $\mathrm{R}$ square sebesar 0,409 , ini berarti besarnya hubungan atau pengaruh penggunaan media sosial facebook secara bersama sama terhadap perilaku komunikasi ialah sebesar 40,9\%. Hal ini menunjukkan pengaruh yang terjadi antara variabel bebas yaitu penggunaan media sosial facebook dengan variabel terikat yaitu perilaku komunikasi adalah pengaruh yang cukup kuat. Dengan demikian diketahui bahwa sumbangan ataupun kontribusi antara penggunaan media sosial facebook dan youtube terhadap perilaku komunikasi ialah sebesar 40,9\% sedangkan sisanya 59,1\% dipengaruhi oleh faktor lain. 


\section{DAFTAR PUSTAKA}

Ardianto, Elvinaro dkk, (2004). Komunikasi Massa: Suatu Pengantar. Bandung : Sembiosa Rekatama Media

Arifin, Hasnul. (2009). Nongkrong Asyik di Internet Dengan Facebook. Jakarta: Buku Kita

Arifin, Anwar. (2006). Ilmu Komunikasi : Sebuah Pengantar Ringkas. Jakarta: Rajawali Pers

Arikunto, Suharsimi, (2002). Prosedur Penelitian Suatu Pendekatan Praktek, Jakarta, Rineka Cipta

Berger, Charles R, dkk. (2015). Handbook Ilmu Komunikasi. Bandung: Nusa Media.

Budiargo, Dian. (2015). Berkomunikasi Ala Net Generation. Jakarta: PT Elex Media Komputindo.

Bungin, Burhan. (2008) Sosiologi Komunikasi : Teori, Paradigma, dan Diskursus Teknologi Komunikasi di Masyarakat.Jakarta: KENCANA

Danang Sunyoto dan Setiawan, Ari, (2013). Buku Ajar Statistik, Yogyakarta: Nuha Medika.

Deswita, 2006. Psikologi Perkembangan. Bandung: Remaja Rosdakarya.

Effendy, Onong Uchjanaya. (2005). Ilmu Komunikasi Teori dan Praktik. Bandung, PT Remaja Rosdakarya

Rosdakarya

(2004). Dinamika Komunikasi, Bandung: PT.Remaja , (2003). Ilmu, teori dan filsafat komunikasi. Bandung: Citra Aditya Bakti

Eysenbach, G. (2008). Medicin 2.0: Social Networking, Collaboration, Participation, Apomediation, and Openness. Journal of Medical Internet Research 2008; 10(3): e22

Hardjana, Agus. (2007). Komunikasi Intrapersonal dan Interpersonal. Yogyakarta: Kanisius Media.

Kincaid, Lawrence dan Schramm, Wilbur. (2007). Asas-Asas Komunikasi Antarmanusia (terjemahan: Agus Setiadi). Jakarta: LP3ES-EWCI.

Mardalis, 2003. Metode Penelitian Suatu Pendekatan Proposal, Cet.VI, Jakarta, Bumi Aksara

Mardiana, Wati dan Rizky, A, R, (2009). 5 Jam Menjadi Terkenal Lewat Facebook, Bandung : C.V Yrama Widya.

Marhaeni, Fajar. (2009). Ilmu Komunikasi Teori dan Praktek. Jakarta: Graha ilmu.

McQuail, Denis. (2011). Teori Komunikasi Massa McQuail Edisi 6 Buku 1. Jakarta: Salemba Humanika.

Mulyana, Deddy (2008). Ilmu Komunikasi Suatu Pengantar, (Bandung, PT Remaja Rosdakarya,

Nasrullah, Rulli. (2015). Media Sosial. Remaja, Bandung: Rosdakarya,

Rakhmat, Jalaluddin, (2011). Psikologi Komunikasi; Bandung: PT Remaja Rosdakarya,

Riduwan (2006). Metode Dan Teknik Menyusun Tesis Bandung: Alfabeta.

Rivai,Veithzal, (2009). Kepemimpinan dan Perilaku Organisasi, Jakarta: Rajawali Press.

Rusman, dkk, (2011), Pembelajaran Berbasis Teknologi Informasi dan Komunikasi: Mengembangkan Profesionalisme Guru. Jakarta:Rajawali Pers. PT. Raja Grafindo Persada

Santrock, John W. (2003), Adolescence. Perkembangan Remaja. Edisi Keenam. Jakarta: Erlangga. 
Sanusi, A, (2003). Metodologi Penelitian Praktis, Malang: Buntara Media.

Saputra, Angga. (2010). Analisis Pengaruh Kepuasan, Kualitas, Dan Experiential Marketing Terhadap Word Of Mouth Situs Jejaring Sosial Facebook Pada Mahasiswa Fe Undip Semarang. Skripsi Universitas Dipenogoro

Rumini, Sri dan Sundari, S (2004), Perkembangan Anak dan Remaja,Jakarta: PT. Asdi Mahasatya

Sugiono, (2011). Metode Penelitian Pendidikan Pendekatan Kuantitatif, Kualitatif, Bandung, Alfa Beta , (2006). Statistik Untuk Penelitian, Bandung: Alfabeta.

Sunyoto, Danang, (2013). Statistik Non Parametrik. Yogyakarta: Nuha Medika. , (2005). Statistika untuk Penelitian, Bandung, Alfa Beta

Suranto, AW. (2011). Komunikasi Interpersonal. Yogyakarta: Graha Ilmu.

Umar, Husein, (2008). Metode Penelitian Untuk Skripsi dan Tesis Bisnis. Jakarta: PT Rajagrafindo Persada

Wiryanto. (2004). Pengantar Ilmu Komunikasi. Jakarta:PT.Gramedia Widiasarana Indonesia.

\section{Sumber lain.}

APJII (Asosiasi Penyelenggara Jasa Internet Indonesia). 2016. Survey Penetrasidan Perilaku Pengguna Internet Indonesia. Halaman: 10. https://apjii.or.id/survei2016/download/3zkcUWB5KLNporYEVFR4A0tIuDZehf/htt ps://www.apjii.or.id/. Diakses pada tanggal 22 Oktober 2018

Inayah, M. 2014. Komunikasi Antarpribadi. [Online]. Tersedia: http://digilib.uinsby.ac.id/513/4/Bab\%202.pdf, diakses pada 3 Juni 2019. 
Persepsi : Communication Journal

e-ISSN 2623-2669

Vol 2 No. 2, 2019, 11-44

DOI: https://doi.org/10.30596/persepsi.v2i2.3940 